Article

\title{
Lithium-Ion Batteries: Thermal Behaviour Investigation of Unbalanced Modules
}

\author{
Odile Capron*, Ahmadou Samba, Noshin Omar, Thierry Coosemans, Peter Van den Bossche \\ and Joeri Van Mierlo
}

MOBI-Mobility, Logistics and Automotive Technology Research Centre, Vrije Universiteit Brussel, Pleinlaan, 2, Brussels 1050, Belgium; E-Mails: Ahmadou.Samba@vub.ac.be (A.S.); noshomar@vub.ac.be (N.O.); thierry.coosemans@vub.ac.be (T.C.); pvdbos@vub.ac.be (P.V.B.); jvmierlo@vub.ac.be (J.V.M.)

* Author to whom correspondence should be addressed; E-Mail: ocapron@vub.ac.be;

Tel.: +32-2-629-3396.

Academic Editors: Cornelia A. Bulucea and Nikos E. Mastorakis

Received: 3 June 2015 / Accepted: 23 June 2015 / Published: 29 June 2015

\begin{abstract}
In this paper, the thermal behaviour of an unbalanced battery module made of large lithium iron phosphate cylindrical cells of $18 \mathrm{Ah}$ nominal capacity is investigated during its discharge with $18 \mathrm{~A}, 54 \mathrm{~A}$ and 90 A currents. For this study, several cells were assigned in the module to 5\%,10\% and $20 \%$ initial depth of discharge (DoD). The thermal management of the cells in the module is achieved based on a forced air cooling. The computations of the temperature distribution inside the cells and the module are performed with a two-dimensional modelling approach. During the discharges, the cells with a non-zero initial DoD show a more pronounced temperature increase up to $5 \%$ compared to the reference cells. In the end of the three discharges, the highest temperatures $26.5^{\circ} \mathrm{C}(18 \mathrm{~A})$, $29.6{ }^{\circ} \mathrm{C}(54 \mathrm{~A})$ and $32.3{ }^{\circ} \mathrm{C}(90 \mathrm{~A})$, respectively, are reached for the cells with the highest initial DoD. For these cells, with the increase in the current rate, the highest amount of total heat exceeds $25 \mathrm{~W}$. The reactive and the active heats are found to be the main contributors to the total heat generated by the cells. This study provides the effect of the initial DoD of the cells on the temperature development occurring in an unbalanced battery module during its discharge.
\end{abstract}

Keywords: unbalanced module; lithium iron phosphate; cylindrical cells; temperature distribution; two-dimensional modelling 


\section{Introduction}

With their sustainable character and reliable performances as energy storage systems, batteries represent more than ever a relevant solution for use in current and future electromobility [1-5]. However, temperature affects the performances of the batteries and the overall performances of the electric vehicles by influencing, among others, their lifetime, their power and energy capabilities and their reliability [6,7]. For lithium-ion batteries, the best operating temperatures are in the range between $25^{\circ} \mathrm{C}$ and $40{ }^{\circ} \mathrm{C}$ [7]. To avoid the occurrence of an excessive temperature rise [8] leading to the degradation in their lifetime or, even worse, to the thermal runaway phenomenon, the local temperature of lithium-ion batteries should be carefully monitored. For a battery module, the operating temperature and the uniformity of the temperature distribution are two important factors [9]. Inside the modules, the non-uniformity of the temperature can even lead to the non-uniformity of the performances of the individual cells [6].

For these reasons, battery thermal management systems are developed for these modules. The goal of these systems is to regulate the temperature of the cells in the battery module to extend their lifetime and increase their performances by keeping the cells in their best operating ranges. These systems are either active or passive and should be designed based on the conditions in which the modules will operate. To avoid premature aging of the cells leading to the increase in their internal resistance and their capacity loss, battery management systems should be able to keep the differences between the temperature of the cells less than $5{ }^{\circ} \mathrm{C}$ [10]. Passive thermal management with a thermal phase change material, such as graphene, has been demonstrated to be suitable in [11,12] for lithium ion batteries and particularly for cylindrical cells. Passive thermal management solutions via enhancement of lithium-ion battery electrodes have also been investigated in [13] with multi-walled carbon nanotubes to achieve a higher in-plane thermal conductivity of the electrodes and in [14] with a very thick anode to achieve high thermal and electrical conductivity, respectively. In the case of active systems, thermal management can either be air- or liquid-based. Compared to liquid-based thermal management, air-based systems are less expensive, because no additional costs are required for the implementation of cooling channels into the structure of the modules [10]. The air in the air-based thermal management systems is blown from the heat exchanger towards the cells inside the module, which in turn blows the heated air out of the module.

In the literature, research has been done on the thermal management of battery modules implementing a forced air cooling.

For modules made of cylindrical cells, a three-dimensional electro-thermal model has been achieved in [15] for the study of a battery module made of 26,650 (0.026 m diameter) cells. A three-dimensional electrochemical-thermal model was developed in [16] for the investigation of a battery module made of 18,650 (0.018 m diameter) cylindrical cells. For the study of an in-line battery module made of 26,650 cylindrical cells, the authors in [17] used a two-dimensional computational fluid dynamics model in which the heat generation has been derived from a temperature-dependent correlation of the electrical resistance of the cells. For the thermal management study of a battery module made of $\mathrm{LiMn}_{2} \mathrm{O}_{4}$ cylindrical battery cells, a two-dimensional computational fluid dynamics model has been developed in [18].

However, most of this research focused on modules made of small-size cylindrical cells with low capacity values and always considered that all of the cells in the module have the same initial depth of 
discharge (DoD). In practice, differences in the initial DoD of the cells in a battery module can occur. As mentioned in [19], the series connection of the cells in a module can be used in electric vehicles (EVs) and hybrid electric vehicles (HEVs) to allow one to reach the required voltages. Although in this configuration, even if the current in each cell is the same, voltage differences from cell to cell may occur. During their discharge and their charge, because of the voltage unbalances, the weakest cells in the module will reach the cut-off voltage first and suffer from over-discharge or over-charge. In the worst case (e.g., failure of the balancing system of the battery module), these weakest cells may lead to fast and large internal temperature increases inside the cells and to reductions of the performances of the module. So far in the literature, no two-dimensional study has been conducted regarding the thermal behaviour of battery modules made of large cylindrical cells, and no specific study has been addressed regarding the thermal behaviour during the discharge of unbalanced battery modules, including cells at different initial depths of discharge.

It is why in this paper, the thermal behaviour of an unbalanced battery module is achieved through its analysis during a discharge performance test defined by several discharges at different constant current rates and a $25{ }^{\circ} \mathrm{C}$ operating temperature. The studied battery module is made of large-size $(0.06 \mathrm{~m}$ diameter) cylindrical lithium iron phosphate cells of 18 Ah nominal capacity. For the modelling, a two-dimensional approach has been used. Based on this modelling approach, the effects of the initial depth of discharge of the cells, the discharge current rate and the inlet air velocity on the temperature distribution inside the battery module are investigated. The results demonstrate an increase in the temperature and the heat generation of the cells with the increase in the initial DoD and the discharge current rate applied to the cells.

\section{Module Description}

In the context of a previous study, the thermal conductivity of large-size cylindrical cells in the longitudinal direction was observed to be much greater compared to the thermal conductivity value in the radial direction [20]. Therefore, for a single cell, the temperature gradients observed in the longitudinal direction are significantly lower in value compared to the ones in the radial direction. Considering the smaller temperature difference in the longitudinal direction of each single cell at the end of a 90 A constant current discharge compared to the radial direction, a reduced two-dimensional thermal study of the module is achieved in this paper. With its accuracy and its reduced computational time, this two-dimensional modelling approach is suitable for the study of battery modules made of large cylindrical cells, as investigated in this paper. The schematic of the module is presented in Figure 1. The distance from the top and the bottom of the cells to the sides of the module, as well as the distance from the left- and right-hand side of the cells to the sides of the module are equal to $0.01 \mathrm{~m}$.

For the thermal management of the module, a forced air cooling is implemented with air entering in the module with a mass flux $j_{m}\left(\mathrm{~kg} / \mathrm{m}^{2} \cdot \mathrm{s}\right)$. 


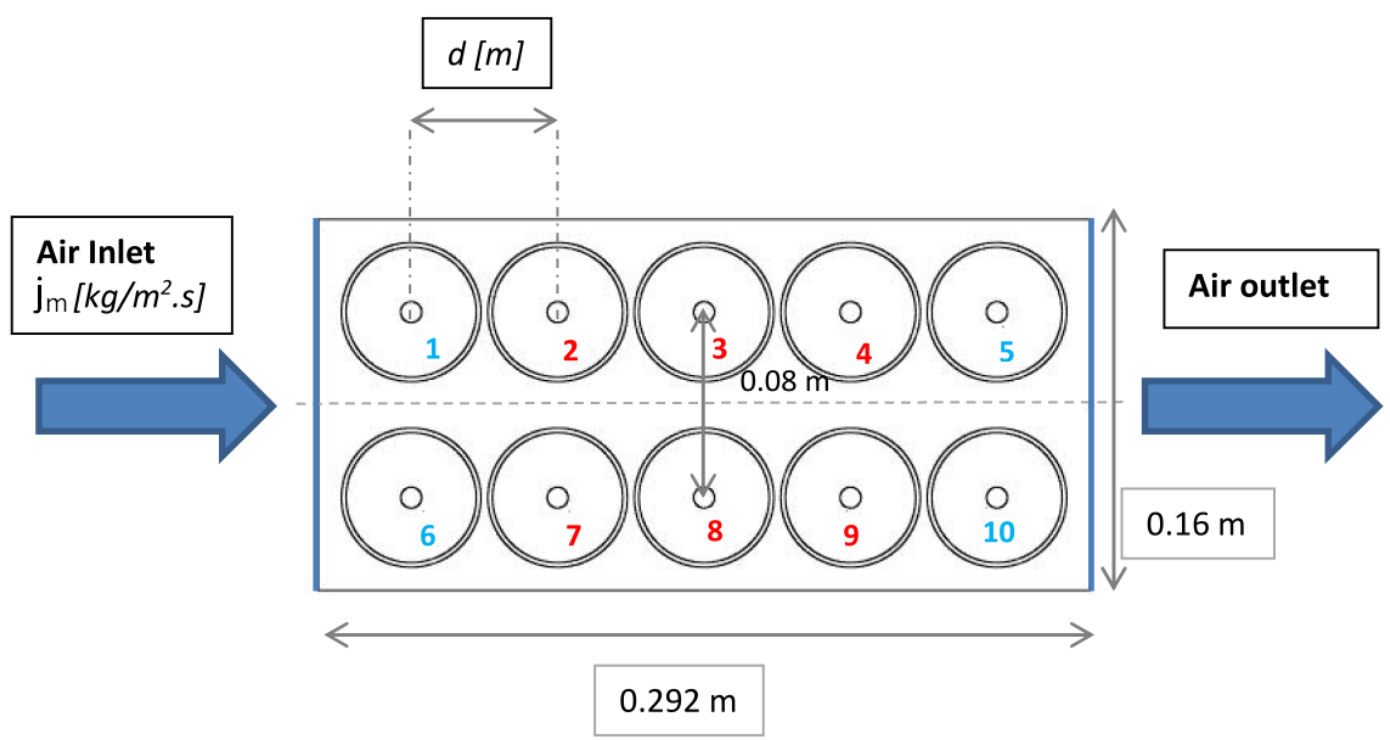

Figure 1. Schematic of the battery module.

\section{Mathematical Modelling of the Module}

The modelling of the large-size and high-power lithium iron phosphate cylindrical cells (GAIA HP 601300 LFP) involves different length scale physics. In order to study the thermal behaviour of these cells, a coupled electrochemical-thermal model was implemented, whose input parameters are the electrical, the chemical and the thermal parameters of the cells. COMSOL Multiphysics $4.3{ }^{\circledR}$ and MATLAB R2012a ${ }^{\circledR}$ were used as simulation tools for the solving and the processing of the multi-scale equations governing the behaviour of the module and the cells.

\subsection{Governing Equations}

\subsubsection{Electrochemical Equations of the Cells}

In this study, the electrochemical modelling of the cells is based on the pseudo-two-dimensional (P2D) model of Doyle et al. [21,22]. The governing non-linear partial differential equations (PDEs) and their constitutive equations are summarized in Table 1 for the modelling of the behaviour of the cells by means of transport phenomena and electrochemical relationships.

During the discharge of the cells, the electrochemical processes are characterized by the conversion of the chemical energy into electrical energy and vice versa during the charge of the cells. These energy conversions are observed at the solid electrolyte interface (SEI) according to the electrochemical reactions taking place at the cathode (Equation (1)) and the anode (Equation (2)).

$$
\begin{gathered}
x \mathrm{Li}^{+}+x e^{-}+\mathrm{Li}_{1-x} \mathrm{FePO}_{4} \rightleftharpoons \mathrm{LiFePO}_{4} \\
\mathrm{LiC}_{6} \rightleftharpoons \mathrm{Li}_{1-x} \mathrm{C}_{6}+x L i^{+}+x e^{-}
\end{gathered}
$$


Table 1. Electrochemical governing equations of the cells.

\begin{tabular}{lll} 
Physics & Governing Equations & Mathematical Expressions \\
\hline & Butler-Volmer equation & $j^{L i}=a_{s} \cdot i_{0}\left\{\exp \left(\frac{\alpha_{a} \eta F}{R T}\right)-\exp \left(-\frac{\alpha_{c} \eta F}{R T}\right)\right\}$ \\
Chemical kinetics & Electrode overpotential & $\eta=\left(\phi_{s}-\phi_{e}\right)-U$ \\
& Exchange current density & $i_{0}=k \cdot\left(c_{e}\right)^{\alpha_{a}} \cdot\left(c_{s, \text { max }}-c_{s, e}\right)^{\alpha_{a}} \cdot\left(c_{s, e}\right)^{\alpha_{c}}$ \\
\hline \multirow{2}{*}{ Charge conservation } & Solid phase & $\nabla\left(\sigma^{e f f} \cdot \nabla \phi_{s}\right)-j^{L i}=0$ \\
& Electrolyte phase & $\nabla\left(\kappa^{e f f} \cdot \nabla \phi_{e}\right)+\nabla\left(\kappa_{D}^{e f f} \nabla \ln \left(c_{e}\right)\right)+j^{L i}=0$ \\
\hline Mass Transfer & Species conservation in solid phase & $\frac{\partial c_{s}}{\partial t}=\frac{D_{s}}{r^{2}} \frac{\partial}{\partial r}\left(r^{2} \cdot \frac{\partial c_{s}}{\partial r}\right)$ \\
& Species conservation in electrolyte & $\frac{\partial\left(\epsilon_{e} \cdot c_{e}\right)}{\partial t}=\nabla\left(D_{e}^{e f f} \nabla c_{e}\right)+\frac{1-t^{+}}{F} \cdot j^{L i}$ \\
\hline
\end{tabular}

The electrochemical parameters of the lithium iron phosphate cylindrical cells obtained from the literature are summarized in Table 2. Since the electrochemical parameters are intrinsic to the battery chemistry type, no effects due to the difference in scale between the large-size cylindrical cells and the cylindrical cells in $[23,24]$ were expected nor observed.

Table 2. Electrochemical parameters of the cells.

\begin{tabular}{lccc}
\hline Parameters & Anode & Separator & Cathode \\
\hline Thickness [24], (m) & $3.4 \times 10^{-5}$ & $2.5 \times 10^{-5}$ & $8 \times 10^{-5}$ \\
Active material volume fraction [24], (/) & 0.58 & 0.55 & 0.374 \\
Filler volume fraction [24], (/) & 0.0326 & - & 0.0535 \\
Volume fraction electrolyte, (/) & 0.3874 & 0.45 & 0.5725 \\
Particle radius [24], (m) & $5 \times 10^{-6}$ & - & $5 \times 10^{-8}$ \\
Electrolyte phase $\mathrm{Li}^{+}$diffusion [24], $\left(\mathrm{m}^{2} / \mathrm{s}\right)$ & & $2 \times 10^{-10}$ & \\
Initial electrolyte concentration [23], $\left(\mathrm{mol} / \mathrm{m}^{3}\right)$ & & 2000 & \\
Maximum solid phase concentration [24], $\left(\mathrm{mol} / \mathrm{m}^{3}\right)$ & 30,555 & - & 22,806 \\
\hline
\end{tabular}

For the lithium ion diffusion and the reaction rate coefficients of both negative and positive electrodes, the temperature dependence is considered with the Equations (3) and (4).

$$
\begin{aligned}
D_{s, i} & =D_{s, i, 25^{\circ} \mathrm{C}} \cdot \exp \left(\frac{E_{a, D_{s, i}}}{R} \cdot\left(\frac{1}{298 K}-\frac{1}{T}\right)\right) \\
k_{i} & =k_{i, 25^{\circ} \mathrm{C}} \cdot \exp \left(\frac{E_{a, k_{i}}}{R} \cdot\left(\frac{1}{298 K}-\frac{1}{T}\right)\right)
\end{aligned}
$$


The values for $D_{s, i, 25^{\circ} \mathrm{C}}$ and $E_{a, D_{s, i}}$ and $k_{i, 25^{\circ} \mathrm{C}}$ and $E_{a, k_{i}}$ were equal to $1 \times 10^{-13} \mathrm{~m}^{2} / \mathrm{s}$ and $20 \mathrm{~kJ} / \mathrm{mol}$ for the positive electrode [25] and $3 \times 10^{-14} \mathrm{~m}^{2} / \mathrm{s}$ and $4 \mathrm{~kJ} / \mathrm{mol}$ for the negative electrode [25].

The evolutions of the potential of the anode and the cathode during the discharge of the cells are illustrated in Figure 2. At the anode, an increase in the open circuit potential occurs, while at the anode, a decrease occurs. The variations of these open circuit potentials with the temperature define the entropy coefficient of the electrodes, which are represented in Figure 3.

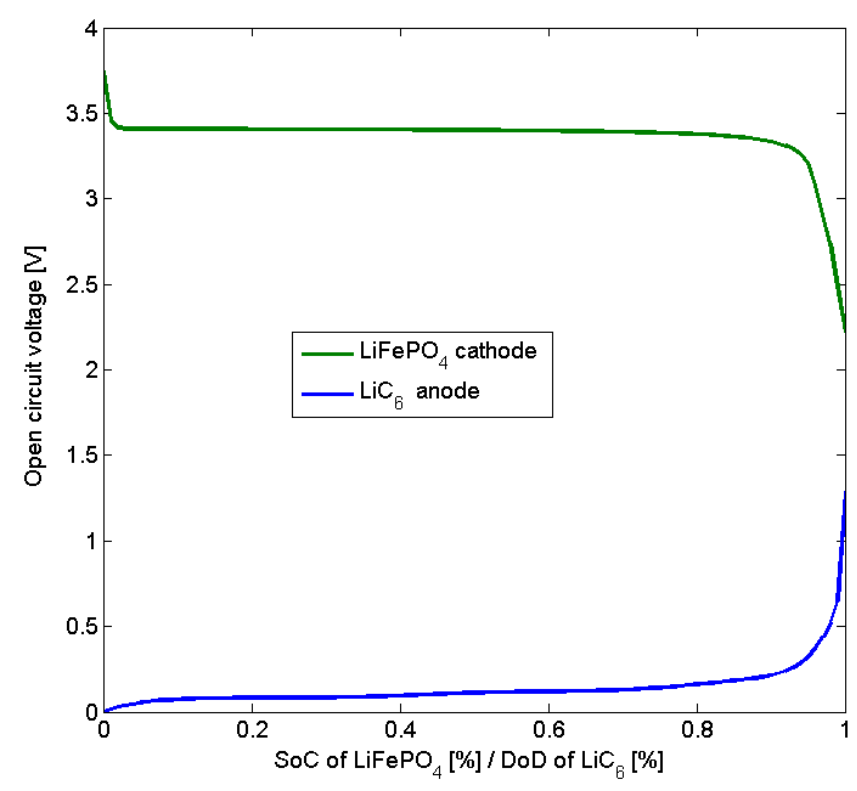

Figure 2. Open circuit potential of the electrodes.

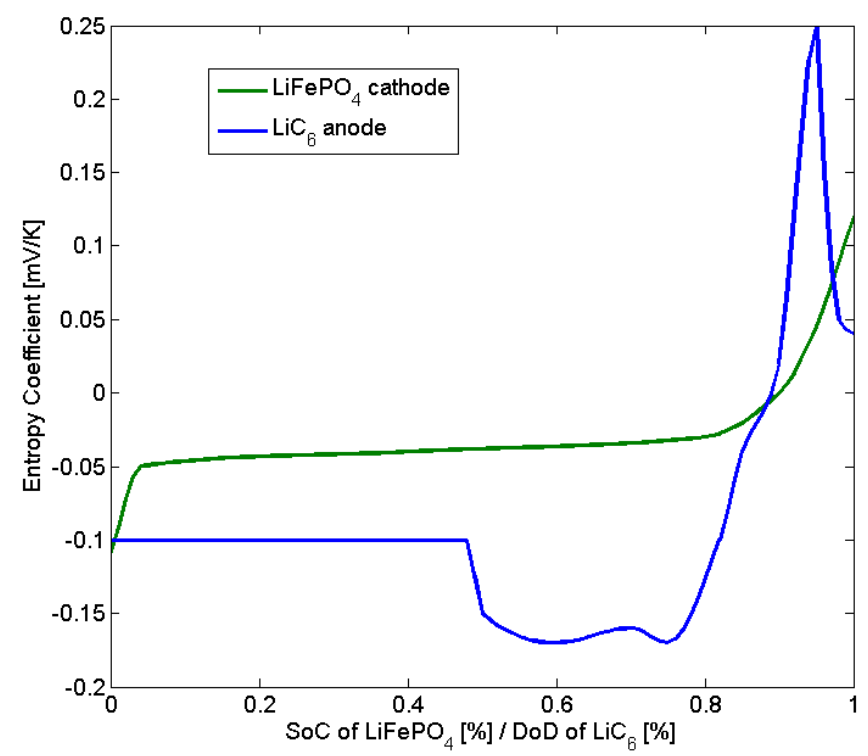

Figure 3. Entropy coefficient of the electrodes.

\subsubsection{Electrochemical-Thermal Equations of the Cells}

The heat equation given by Equation (5) describes the heat transfer occurring between the cells and the air surrounding them: 


$$
\rho c_{p} \cdot \frac{\partial T}{\partial t}=\nabla(k \nabla T)+Q
$$

where $\rho$ represents the density, $c_{p}$ the heat capacity, $T$ the temperature, $k$ the thermal conductivity and $Q$ the heat generation. The internal region, the electrodes and the separator thermo-physical properties of the cells are presented in Table 3.

Table 3. Cell internal region, electrodes and separator thermo-physical properties.

\begin{tabular}{lccc}
\hline Regions & $\boldsymbol{c}_{\boldsymbol{p}}(\mathrm{J} / \mathrm{kg} \cdot \mathrm{K})$ & $\boldsymbol{\rho}\left(\mathrm{kg} / \mathrm{m}^{\mathbf{3}}\right)$ & $\boldsymbol{k}_{\boldsymbol{T}}(\mathrm{W} / \mathrm{m} \cdot \mathrm{K})$ \\
\hline Cell internal region & 1034.2 & 3345.5 & $0.33434\left(k_{T, r}\right)$ \\
& & & $57.515\left(k_{T a n g}\right)$ \\
negative electrode [23] & 1437.4 & 1347.33 & 1.04 \\
positive electrode [23] & 750 & 3600 & 0.20 \\
separator electrode [23] & 1978.16 & 1008.98 & 0.344 \\
negative current collector [23] & 385 & 8933 & 398 \\
positive current collector [23] & 875 & 2770 & 170 \\
\hline
\end{tabular}

To study the thermal behaviour of the cells based on their electrochemical-thermal modelling, the internal region of the cells (or active material region) were considered as homogeneous. With this approach, the properties of the internal region of the cells were defined by the mean values of the thermo-physical properties associated with each layer inside the cells. This is assuming perfect thermal contact existing between the different layers thanks to the electrolyte that surrounds the electrodes and the separator layers and fills in, therefore, the gaps that would lead to differences in the temperature of the different layers. For the modelling, as in Inui et al. [26], the centers of the cells were filled in with air.

In the module, a time varying heat generation and a transient heat transfer are considered for the cells. The heat generation $Q$ inside the cells is derived from Equation (6):

$$
Q=\underbrace{j^{L i} T\left(\frac{\partial U}{\partial T}\right)}_{\text {reactive heat }}+\underbrace{j^{L i}\left(\phi_{s}-\phi_{l}-U\right)}_{\text {active heat }}+\underbrace{\left[\sigma_{s}^{e f f} \nabla \phi_{s} \nabla \phi_{s}+\sigma_{l}^{e f f} \nabla \phi_{l} \nabla \phi_{l}+\kappa_{D}^{e f f} \nabla \ln \left(c_{l}\right) \nabla \phi_{l}\right]}_{\text {ohmic heat }}
$$

where $j^{L i}$ is the transfer current due to the intercalation or deintercalation of lithium ions, $\phi_{s}$ is the potential of the solid phase, $\phi_{l}$ is the potential of the electrolyte phase, $U$ is the open circuit voltage, $T$ is the temperature, $\sigma_{s}^{\text {eff }}$ is the effective value of the electrical conductivity of the solid phase, $\sigma_{l}^{\text {eff }}$ is the effective value of the electrical conductivity of the electrolyte phase and $c_{l}$ represents the concentration of the electrolyte [27]. By definition, $\kappa_{D}^{e f f}$ is given by Equation (7):

$$
\kappa_{D}^{e f f}=\frac{2 R T \sigma_{l}^{e f f}\left(1-t_{+}\right)}{F}
$$


where $R$ represents the universal gas constant equal to $8.314 \mathrm{~J} / \mathrm{mol} \cdot \mathrm{K}, T$ is the temperature, $\sigma_{l}^{\text {eff }}$ is the effective electrical conductivity of the electrolyte, $t_{+}$is the transference number of lithium ions and $F$ represents the Faraday constant, which is equal to $96,485 \mathrm{C} / \mathrm{mol}$ [27].

The first term in Equation (6) defines the reactive heat; the second term defines the active heat; while the third one (in brackets) defines the ohmic heat generation [23,28]. By definition, the active and the reactive heat generations take place at the negative and the positive electrodes, while the ohmic heat generation originates from the electrolyte and both the negative and positive electrodes. To convert the volumetric heat generation given by Equation (6) into a heat generation expression in Watts, Equations (8) and (9) [29] are introduced:

$$
\begin{gathered}
L=\pi N \frac{(D+d)}{2} \\
V_{i}=2 w_{i} h L
\end{gathered}
$$

where $L$ represents the total length of the spiral formed by the layered internal region of the cell, $N$ is the total number of layers inside the cell, $D$ is the diameter at the end of the spiral (or the cell diameter), $d$ is the diameter at the beginning of the spiral (or the internal diameter of the cell), $V_{i}$ is the volume of a layer, $w_{i}$ is the width of a layer inside the cell, $h$ is the height of the cell and $i$ identifies each layer.

\subsubsection{Thermo-Hydrodynamic Equations of the Module}

The modelling of the thermal behaviour of the air flow in the module is achieved with the two-dimensional formulation of the Navier-Stokes equations (conservation of mass, conservation of momentum and conservation of energy) defined in Table 4. In these equations, the air flow is considered as steady $\left(\frac{\partial v}{\partial t}=0\right)$, and its properties at the entrance temperature are assumed to be constant in time $\left(\frac{\partial \rho}{\partial t}=0\right)$.

Table 4. Navier-Stokes equations.

\section{Conservation Equations Mathematical Expressions}

$$
\begin{array}{ll}
\text { Conservation of mass } & \nabla(\rho v)+\frac{\partial \rho}{\partial t}=0 \\
\text { Conservation of momentum } & v \nabla(v)+\frac{1}{\rho} \cdot \frac{\partial p}{\partial x}-\nu(\nabla)^{2} \cdot v+\frac{\partial v}{\partial t}=0 \\
\text { Conservation of energy } & v \nabla(T)-\frac{k}{\rho \cdot c_{p}} \cdot\left(\nabla^{2} T\right)+\frac{\partial T}{\partial t}=0
\end{array}
$$




\subsection{Boundary Conditions}

At the entrance of the module, the temperature is set constant to $25^{\circ} \mathrm{C}$, and the velocity of the inlet air is considered to be unidirectional in the axial direction: $v_{x}=v(\mathrm{~m} / \mathrm{s})$ and $v_{y}=0(\mathrm{~m} / \mathrm{s})$. At the exit of the module, a pressure equal to $1 \mathrm{~atm}$ is defined and the normal gradient of the temperature is set to zero: $\frac{\partial T}{\partial n}=0$. To bound the fluid and the solid regions, walls boundaries are defined for the cells and the upper part of the module casing. At the interface between the cells and the air, the no-slip condition is defined, so that the normal velocity of the air is equal to zero. The module is considered to be thermally insulated from the ambient environment, so that no transfer of heat and no variation of the temperature occurs through the outer walls of the module casing: $\frac{\partial T}{\partial n}=0$. The uniformity of the temperature and the heat flux are considered at the interfaces between the cells and the air. To reduce the computational effort of the simulations, a symmetry axis has been introduced in the module, so that the simulations are achieved on its half only. At this symmetry axis, the normal velocity of the air and the normal gradient of the temperature are set to zero: $v_{n}=0$ and $\frac{\partial T}{\partial n}=0$.

\subsection{Numerical Solution and Validation}

The validation of the electrochemical modelling of the cells is achieved in Figure 4 for several constant discharge currents. The experimental tests are defined by the measurements of the voltage of a commercially available GAIA LFP HP 601300 (diameter: $60 \mathrm{~mm}$; height: $159 \mathrm{~mm}$ ) battery cell. The nominal voltage and the nominal capacity specified for this cell are $3.2 \mathrm{~V}$ and $18 \mathrm{Ah}$ (at $0.2 \mathrm{C}$ ), respectively. From the data sheet of the cell, the voltage during the discharge should not go below 2.1 $\mathrm{V}$ (the lower limit for the voltage during discharge). To test the cell at different current rates and to monitor the voltage evolutions, a PEC battery tester was used [30]. The current rates were defined with $1 I_{t}, 3 I_{t}$ and $5 I_{t}$ (i.e., $18 \mathrm{~A}, 54 \mathrm{~A}$ and $90 \mathrm{~A}$ ). The temperature measurements were recorded on the surface of the battery at the mid of its height with a Type $\mathrm{K}$ thermocouple with $\pm 0.1{ }^{\circ} \mathrm{C}$ measurement accuracy, as characterized in [31]. From Figure 4, a good agreement between the experiments and the simulations results is found with less than a $5 \%$ deviation between the experimental and the theoretical voltage (Figure 4a) and temperature (Figure 4b) curves. 

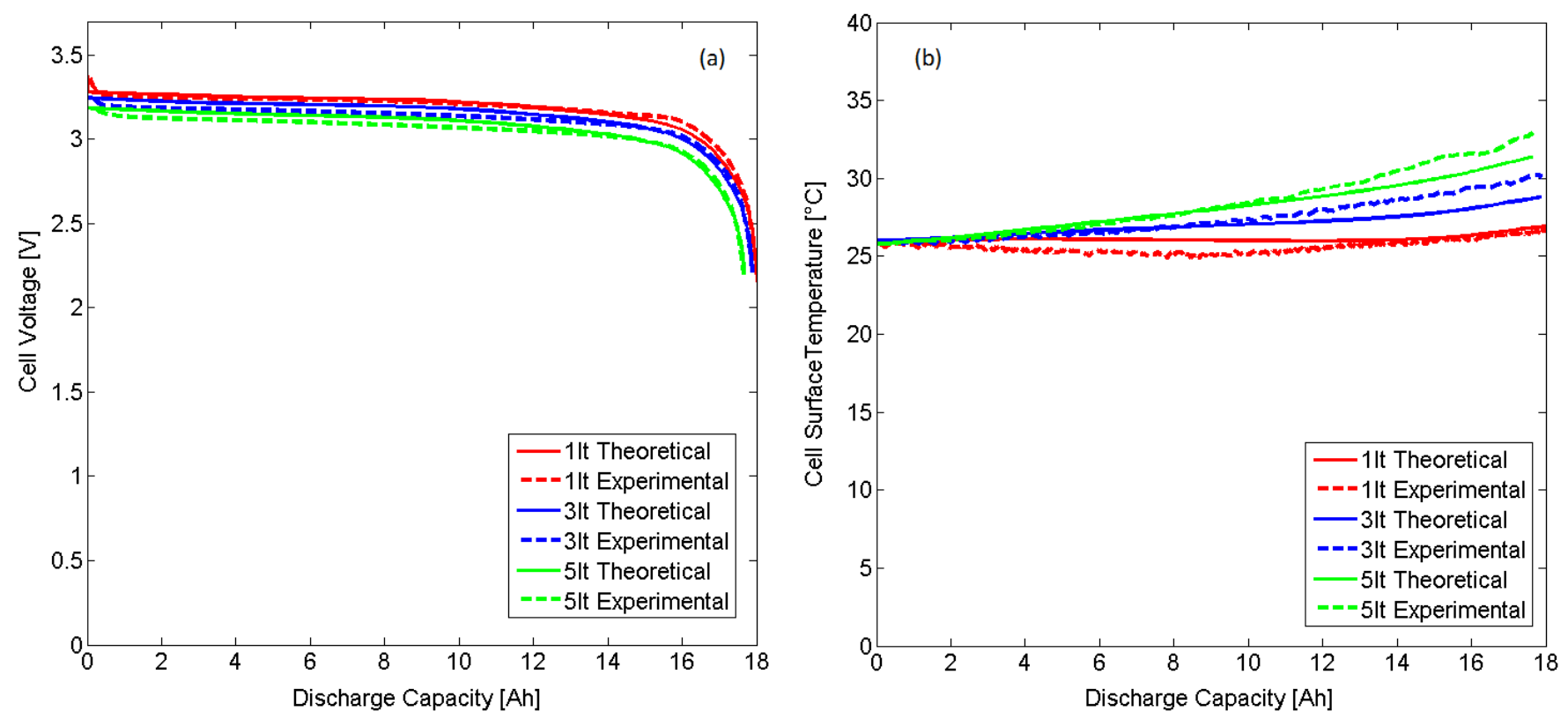

Figure 4. Validation of the voltage (a) and the temperature (b) of the cell.

The numerical simulations of the thermal behaviour of the module are based on the solving of the governing equations for the battery cells and the cooling air on half of the module, by using the symmetry property highlighted in Figure 1. The simulations used a MUMPS (Multifrontal Massively Parallel Solver) time-dependent solver with a relative tolerance of $10^{-3}$ for all of the variables to obtain the solutions for which the mesh independence was verified. The meshing of the module is achieved with 487,562 triangular elements and a 0.000402 maximum element size. The solving of the module governing equations for the computation of the numerical solutions was achieved based on a segregated approach. At each time step, the Navier-Stokes equations are solved at each node of the mesh to compute the temperature and the air velocity inside the module, from which the temperature solution serves as input for the solving of the electrochemical-thermal equations governing the behaviour of the cells.

\section{Results and Discussion}

\subsection{Module Design Considerations}

\subsubsection{Influence of the Cooling}

Figure 5 illustrates the temperature distribution in a module at the end of its discharge with a low (Figure 5a) and a high (Figure 5b) current rate. The module is initially at $25{ }^{\circ} \mathrm{C}$ and is closed, so that it is not cooled with a fluid. With the increase in the current rate, higher temperatures inside the cells are observed in Figure $5 \mathrm{~b}$ because of the higher amount of heat generation. In Figure $5 \mathrm{~b}$, the temperature of the air around the cells also increased significantly due to the increase in the heat generation. Therefore, thermal management is important to avoid too large of an increase in the temperature of the air surrounding the cells, especially during the discharge of a module at high current rates. 

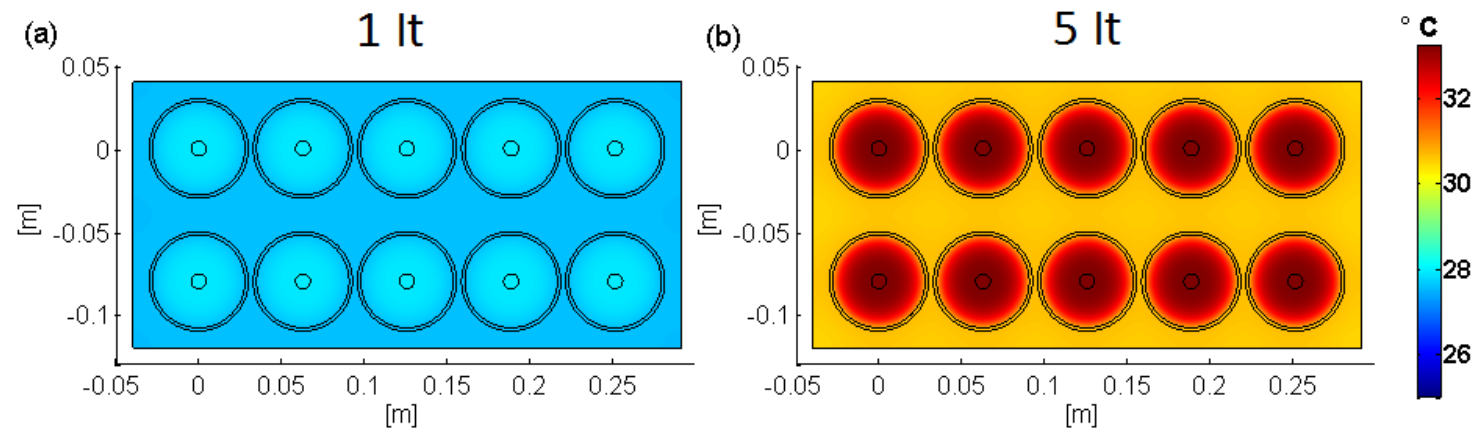

Figure 5. Closed module at the end of (a) 18A and (b) 90A constant current discharges.

\subsubsection{Influence of the Air Flux}

Figure $6 \mathrm{~b}$ illustrates the cooling of a battery module discharged with a high current rate $(90 \mathrm{~A})$. For cooling purposes, a $0.024 \mathrm{~kg} / \mathrm{m}^{2} . \mathrm{s}$ air flux is entering at $25{ }^{\circ} \mathrm{C}$ on the left-hand side of the module.

From Figure 6b, the maximum air velocity is equal to $0.14 \mathrm{~m} / \mathrm{s}$ and is reached in the channel made between the two rows of cells. In the regions between the cells and the upper and lower sides of the module, the air is slowed down by the geometry configurations of the cells in the module. At the end of the discharge, Figure $6 \mathrm{~b}$ indicates lower temperatures (around $25^{\circ} \mathrm{C}$ ) at the front and higher temperatures (around $30^{\circ} \mathrm{C}$ ) at the rear of the module. Therefore, Figure $6 \mathrm{~b}$ emphasises the need for a sufficient inlet air velocity for a proper thermal management of the cells located in the rear of the module.

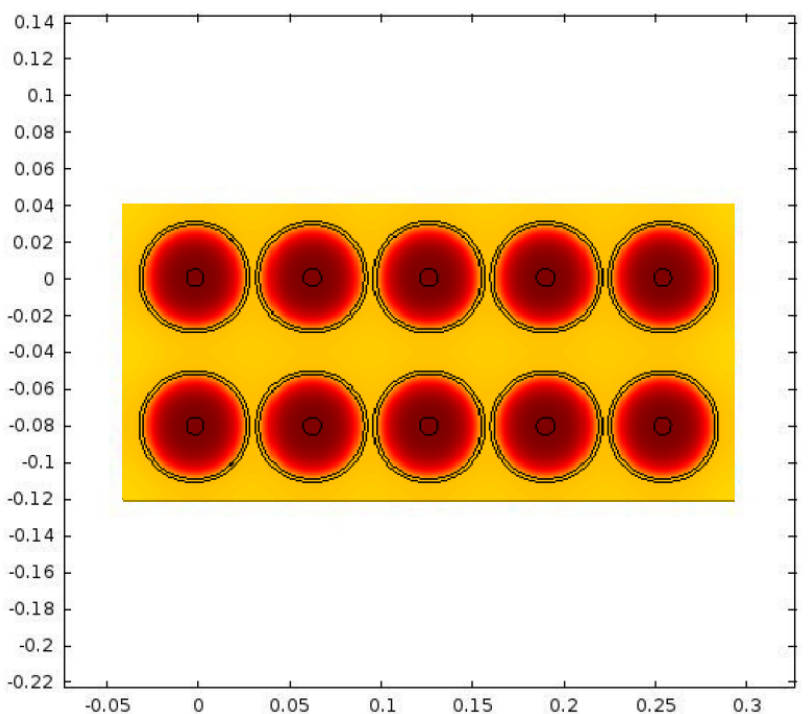

(a)

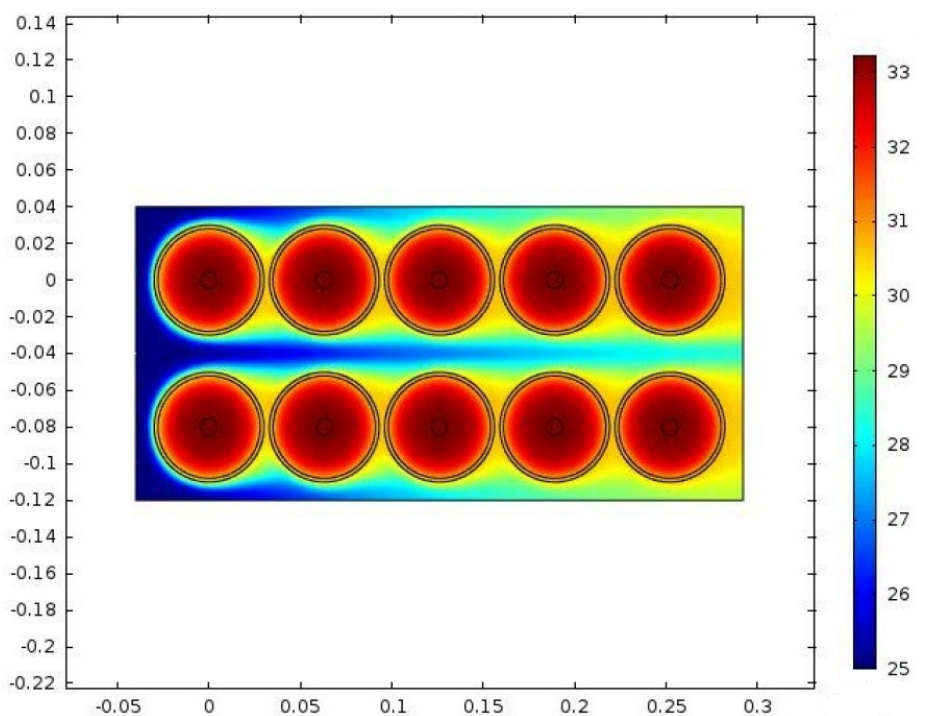

(b)

Figure 6. Temperature distribution at the end of the discharge of a module initially at $25^{\circ} \mathrm{C}$ (a) without cooling and (b) cooled with air $\left(j_{m}=0.024 \mathrm{~kg} / \mathrm{m}^{2} \cdot \mathrm{s}\right)$.

With an increased air flux equal to $0.059 \mathrm{~kg} / \mathrm{m}^{2} \cdot \mathrm{s}$, the maximum velocity of the air between the rows of cells equals now $0.32 \mathrm{~m} / \mathrm{s}$. As a consequence, compared to Figure $7 \mathrm{~b}$, a better cooling of the cells is achieved in Figure $7 \mathrm{~d}$ considering the existence of temperatures around $25^{\circ} \mathrm{C}$ for the air at both the front and rear sides of the module. 

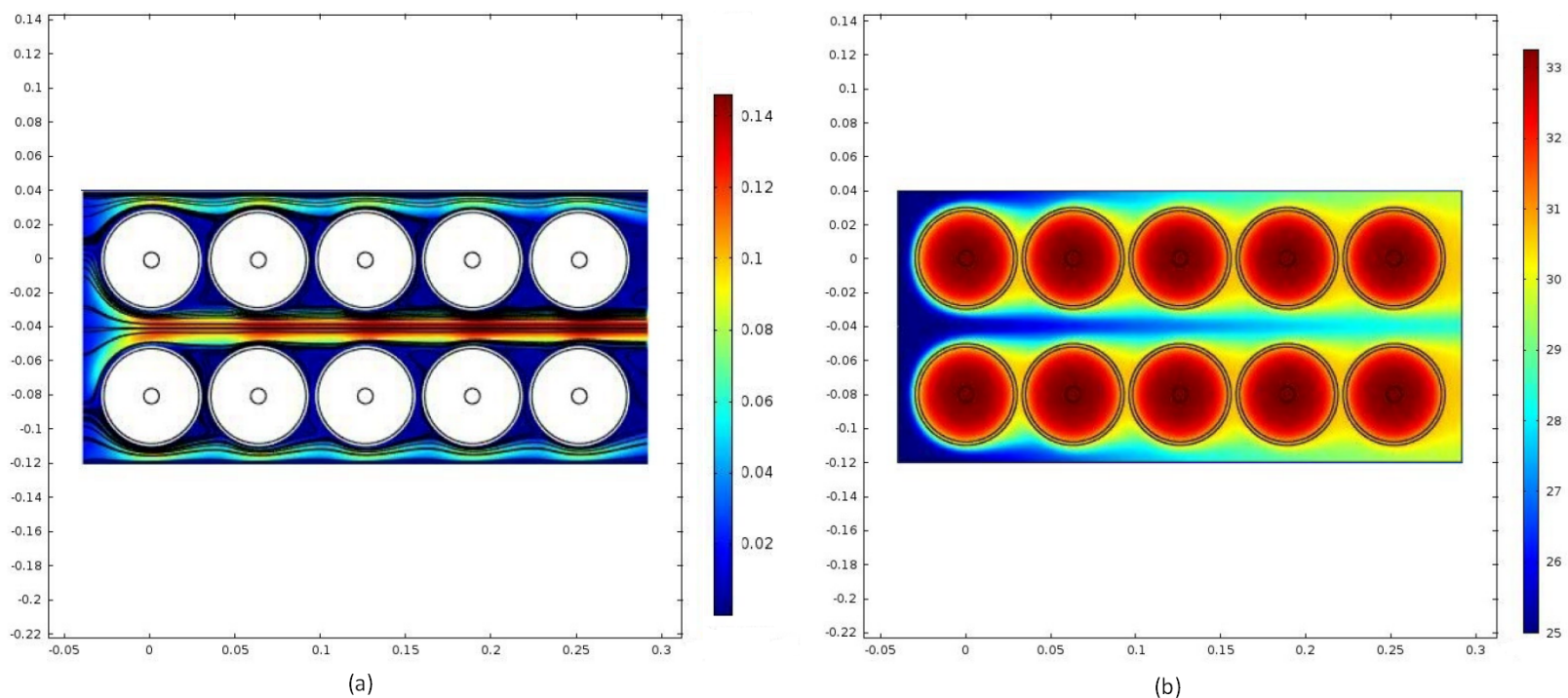

(b)
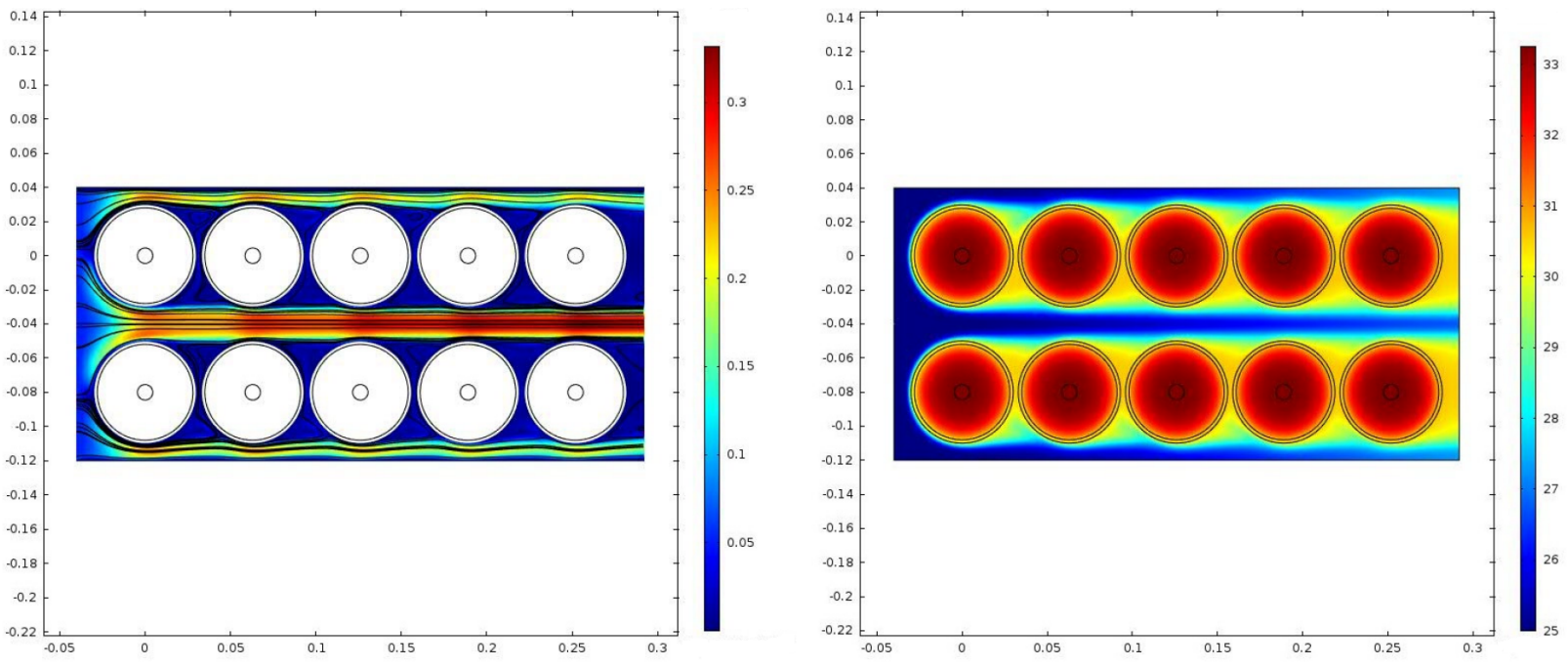

(d)

Figure 7. Air velocity field $(\mathrm{m} / \mathrm{s})(\mathbf{a}, \mathbf{c})$ and temperature distribution $\left({ }^{\circ} \mathrm{C}\right)(\mathbf{b}, \mathbf{d})$ for a cooled module with $0.063 \mathrm{~m}$ cell inter-distance and air fluxes equal to $0.024 \mathrm{~kg} / \mathrm{m}^{2} \cdot \mathrm{s}$ and $0.059 \mathrm{~kg} / \mathrm{m}^{2} \cdot \mathrm{s}$.

\subsubsection{Influence of the Spacing}

To assess the influence of the spacing between the cells on the same row, on the temperature distribution in the battery module, the distance between two consecutive cells has been increased from $0.063 \mathrm{~m}$ (in Figure $8 \mathrm{~b}$ ) to $0.08 \mathrm{~m}$ (in Figure $8 \mathrm{~d}$ ). The air velocity field inside the module is illustrated in Figure 8c. In this figure, the flow of air in between the cells on the same row is facilitated, although because the velocity of the air in these regions has not increased, no significant decrease in the temperature is observed in Figure $8 \mathrm{~d}$ in these regions. Considering this, the spacing between the cells has therefore a rather limited influence on their cooling.

Generally, the evaluation of a battery thermal management system is based on the assessment of its thermal transfer capabilities [10]. This can be done based on the evaluation of the pressure drop throughout the module between its entrance and its exit. In practice, the less the resistance from the 
arrangement of cells, the lower the pressure drop throughout the module will be and the better the cooling of the cells is achieved. After examination, the pressure drop across the module is less than $1 \%$ for both $0.063 \mathrm{~m}$ and $0.08 \mathrm{~m}$ spacings between the cells. In addition, no significant decrease in the temperature is observed between the cells with an increased spacing of $0.08 \mathrm{~m}$ between the cells. Therefore, the module design with $0.063 \mathrm{~m}$ spacing is chosen as a valuable design for study purposes of the unbalanced battery module.
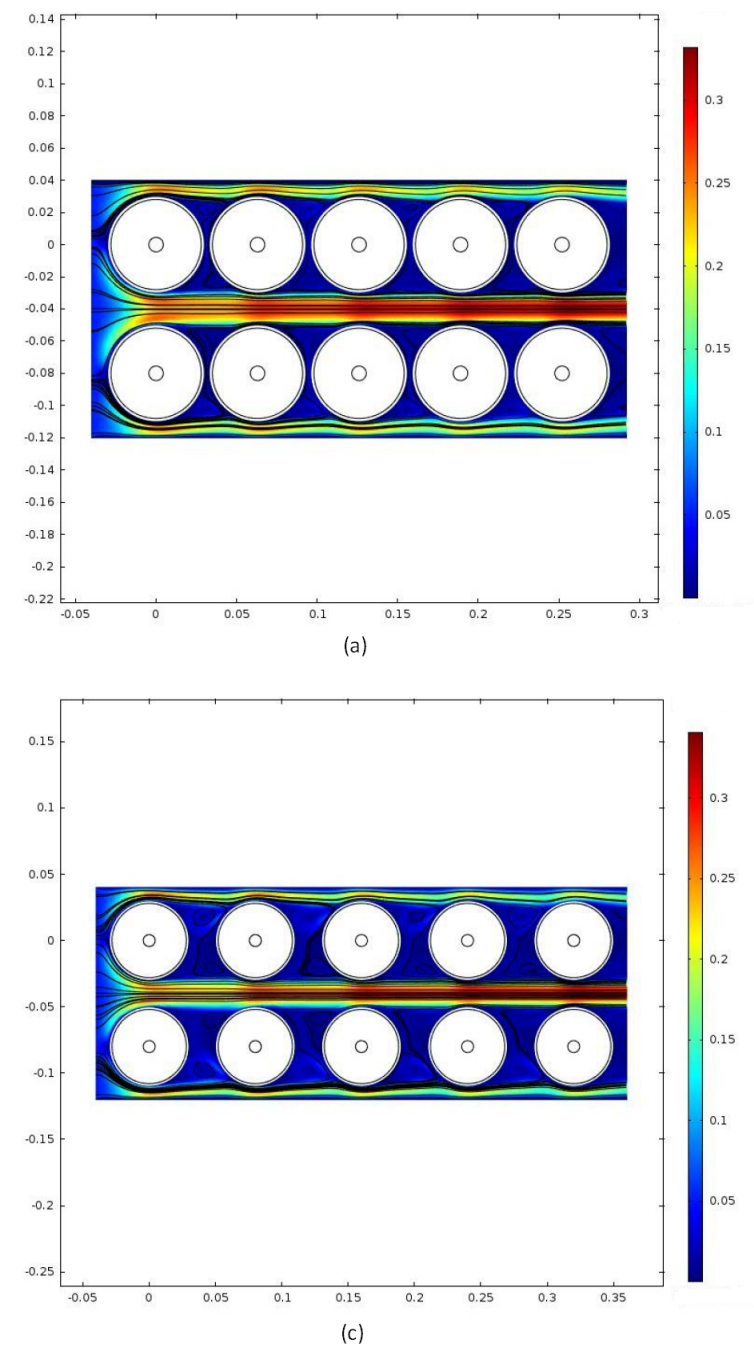

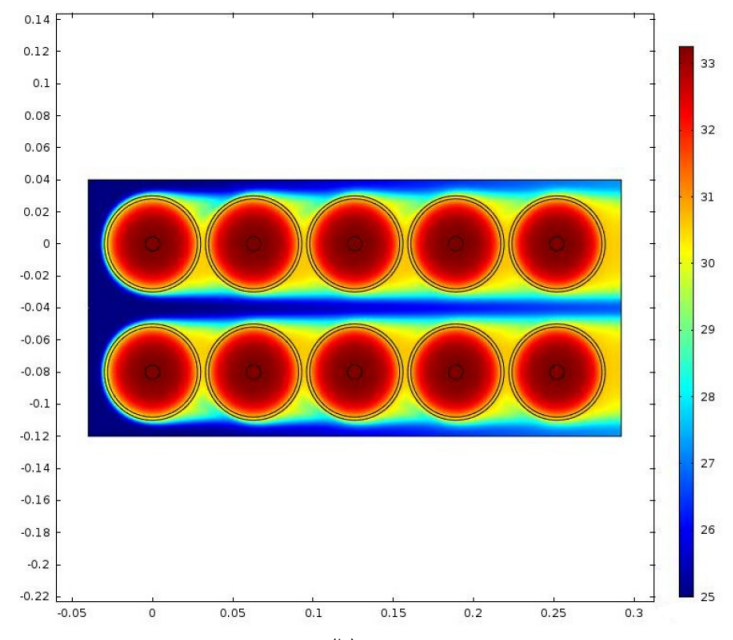

(b)

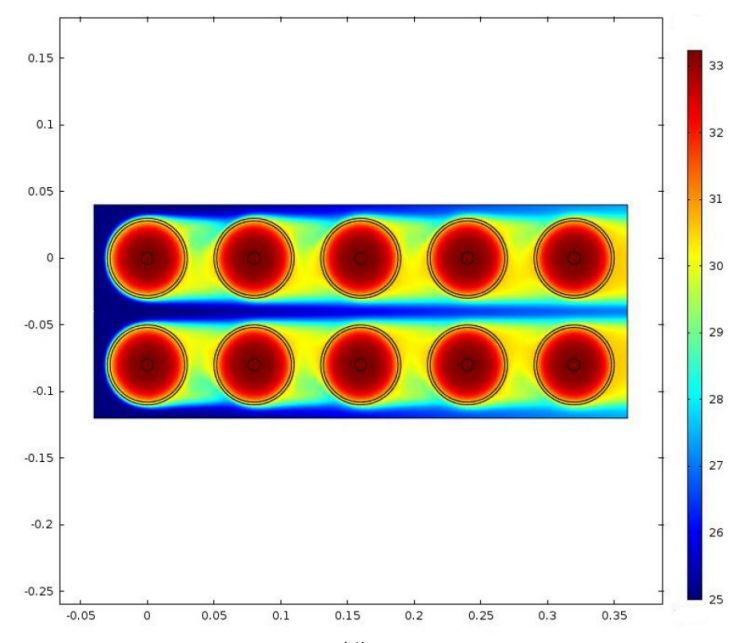

(d)

Figure 8. Cooled module $\left(j_{m}=0.059 \mathrm{~kg} / \mathrm{m}^{2} \cdot \mathrm{s}\right)$ with $0.063 \mathrm{~m}$ and $0.08 \mathrm{~m}$ cells inter-distance: air velocity field $(\mathrm{m} / \mathrm{s})(\mathbf{a}, \mathbf{c})$ and temperature distribution $\left({ }^{\circ} C\right)(\mathbf{b}, \mathbf{d})$.

\subsubsection{Validation of the Computational Fluid Dynamics Model}

The results of the computational fluid dynamics model presented in Sections 4.1.1-4.1.3 are validated with the experimental correlations of the Nusselt number observed in the case of the air flow through a tube bank. For the validation of the simulation results, the experimental correlations of the Nusselt number $N u_{D}$ available from the work of Zukauskas [32] are used. Given that the module corresponds to an in-line bank of tubes with five battery cells in its length, the correlations of the Nusselt number are given by Equation (10) as a function of the Reynolds number $R e_{D}$ and the Prandtl number $\operatorname{Pr}$ properties of the air inside the module. 


$$
\left\{\begin{array}{lc}
N u_{D}=0.93 \times 0.52 \times \operatorname{Re}_{D}^{0.5} \operatorname{Pr}^{0.36} & 100 \leq R e_{D \max } \leq 10^{3} \\
N u_{D}=0.93 \times 0.27 \times R e_{D}^{0.63} \operatorname{Pr}^{0.36} & 10^{3} \leq R e_{D \max } \leq 2.10^{5}
\end{array}\right.
$$

For validation purposes, the theoretical Nusselt number is computed based on the simulations results with Equation (11a), in which the convection coefficient $h$ is determined from the total heat transfer rate from the battery cells to the air surrounding them (Equation (11b)).

$$
\left\{\begin{array}{l}
N u_{D}=\frac{h \cdot D}{k_{f}} \\
\dot{Q}=h N \pi D L \cdot \Delta T_{l m}=\rho v N_{T} S_{T} L \cdot c_{p} \cdot\left(T_{i}-T_{o}\right)
\end{array}\right.
$$

In Equation (11b), $\Delta T_{l m}$ represents the log mean temperature difference, which is described in Equation (12).

$$
\Delta T_{l m}=\frac{\left(\left(T_{w}-T_{i}\right)-\left(T_{w}-T_{o}\right)\right.}{\ln \left(\left(T_{w}-T_{i}\right) /\left(T_{w}-T_{o}\right)\right)}
$$

Table 5 summarizes the results obtained for the Nusselt number based on both experimental correlations and simulations. The comparison of these values outlines the good performances of the CFD model and the simulations of the module with a maximum of $11 \%$ deviation between the theoretical and the experimentally-correlated Nusselt numbers.

Table 5. Comparison of the Nusselt numbers for the CFD model validation.

\begin{tabular}{ccccc}
\hline Cases & $\boldsymbol{R} \boldsymbol{e}_{\boldsymbol{D}}(/)$ & Present Study, $\boldsymbol{N u _ { \boldsymbol { D } } ( / )}$ & Zukauskas [32], $\boldsymbol{N u _ { \boldsymbol { D } } ( / )}$ & Deviation (\%) \\
\hline Figure 7a,b & 538 & 8.91 & 10.01 & 11 \\
Figure 7c,d & 1229 & 21.32 & 19.81 & 7 \\
\hline
\end{tabular}

\subsection{Unbalanced Battery Module}

In an unbalanced battery module, reasonable amounts of cell unbalancing are found in the range between 10\% and 20\% [33]. From Table 6, Cells 2, 3 and 4 (numbered in red in Figure 1) are initially assigned to 5\%, 10\% and 20\% DoD, respectively. The same is valid for Cells 7, 8 and 9. Cells 1, 5, 6 and 10 (numbered in blue in Figure 1) are not assigned to any initial DoD and are therefore considered as reference cells. During the simulations, all of the cells in the battery module are discharged with $18 \mathrm{~A}, 54 \mathrm{~A}$ and $90 \mathrm{~A}$ constant currents (or $1 I_{t}, 3 I_{t}$ and $5 I_{t}$, where $I_{t}$ represents the discharge current in amperes during one hour discharge according to the IEC61434 standard). 
Table 6. Initial depth of discharge of the cells

\begin{tabular}{cc}
\hline Cell number & Initial Depth of Discharge \\
\hline 2 & $5 \%$ \\
3 & $10 \%$ \\
4 & $20 \%$ \\
\hline
\end{tabular}

\subsubsection{Voltage of the Cells}

Figure 9 shows the voltage of the cells in the module initially at different DoD during their discharges at $1 I_{t}, 3 I_{t}$ and $5 I_{t}$ current rates. Figure 9 emphasises the faster voltage drop of the cells in time, with the increase in their initial DoD and the discharge current rate.

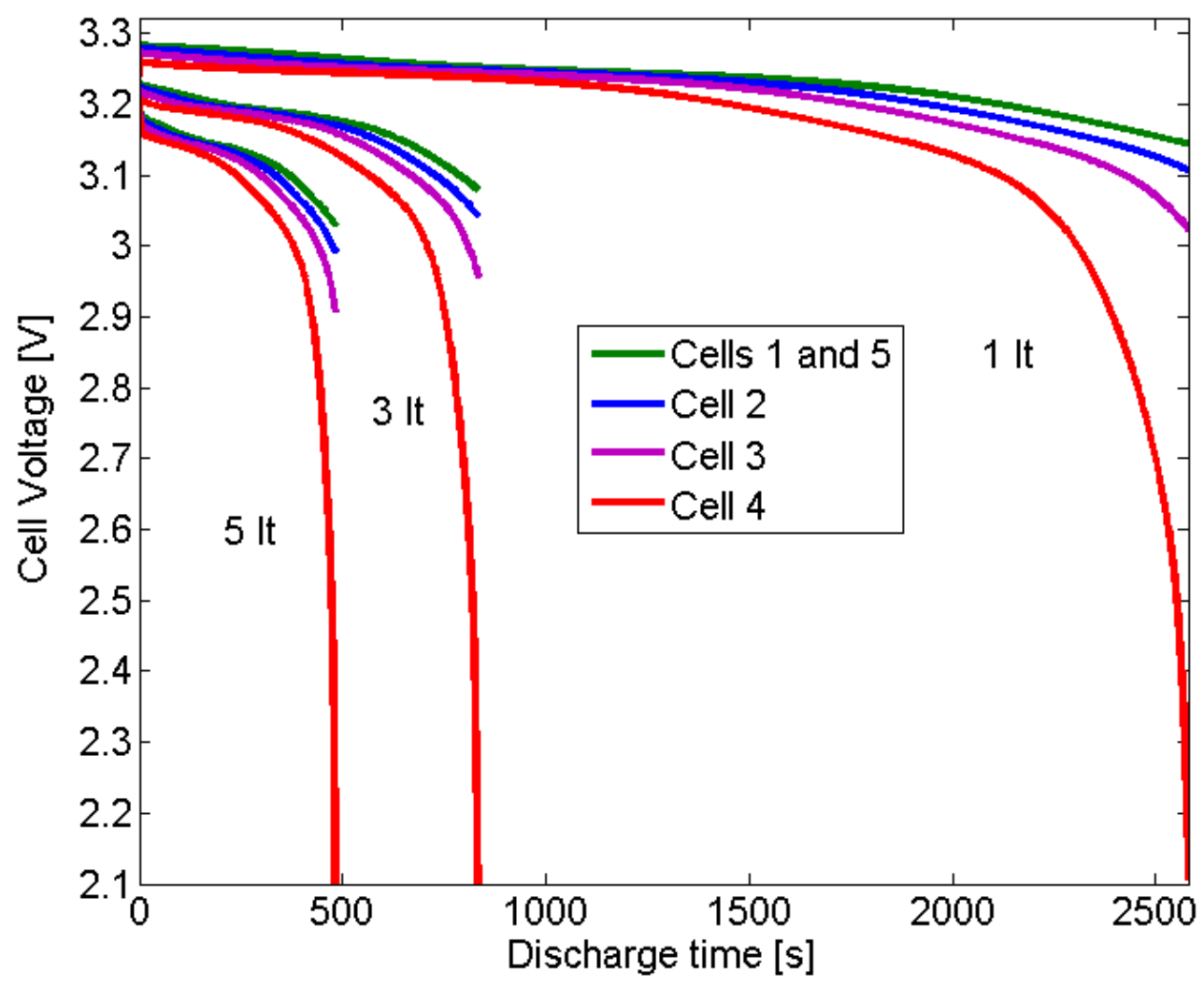

Figure 9. Voltage of the cells during their discharge with different current rates.

\subsubsection{Temperature Distribution}

The temperature distribution inside the unbalanced battery module at the end of its discharge with $18 \mathrm{~A}, 54 \mathrm{~A}$ and $90 \mathrm{~A}$ is highlighted in Figure 10d-f. In the end of the $90 \mathrm{~A}$ discharge in Figure 10f, the cells in the module show higher internal temperatures compared to Figure 10d. At the end of all of the discharges, the cells with 20\% initial DoD show the highest temperature in the module. The highest temperature in the internal region of these cells is observed because more heat is generated inside these cells at the end of the discharges compared to the other cells. From Figure 10a-c, at the end of the discharge of the cells with $18 \mathrm{~A}$, the temperature of Cell 4 with $20 \%$ initial DoD has increased by $1.5^{\circ} \mathrm{C}$ 
or $6 \%$, while at the end of the discharge with $90 \mathrm{~A}$ an increase equal to $7.3{ }^{\circ} \mathrm{C}$ or $29 \%$ is observed in the temperature of this cell.

(a)

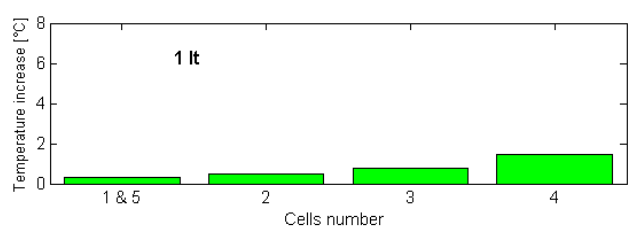

(b)

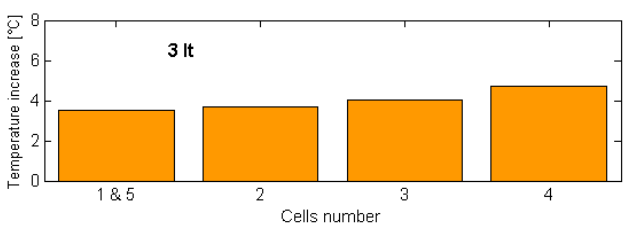

(c)

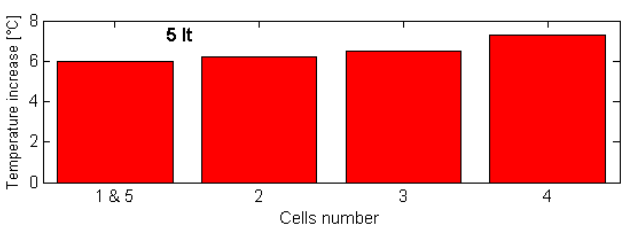

(d)

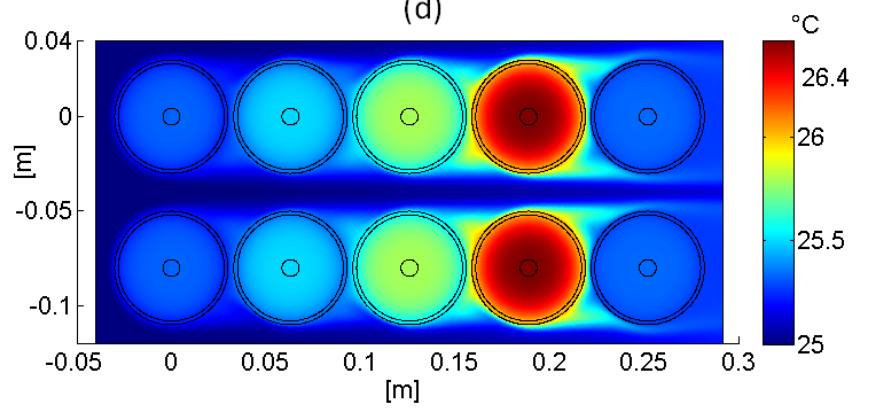

(e)

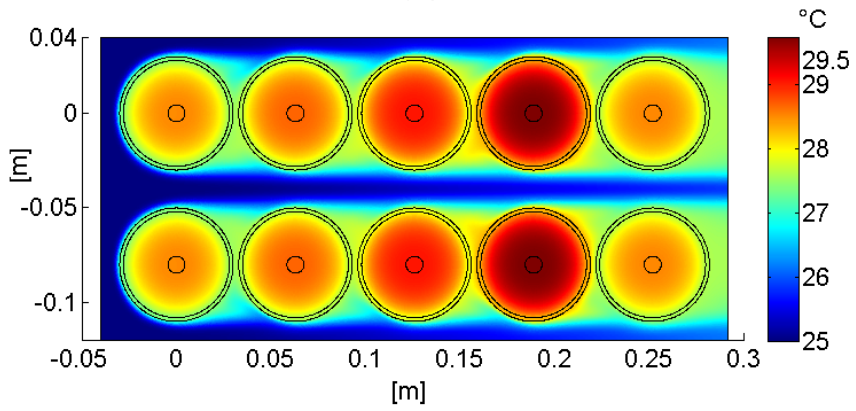

(f)

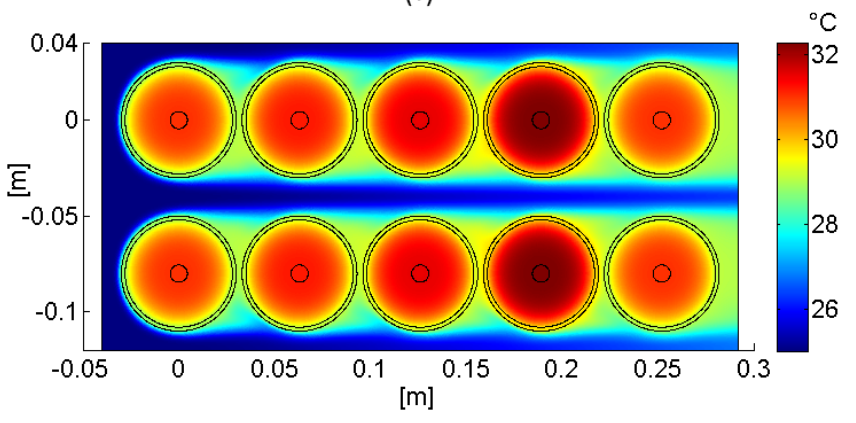

Figure 10. Temperature increase of the cells and temperature distribution in the module after its discharge with $18 \mathrm{~A}(\mathbf{a}, \mathbf{d}), 54 \mathrm{~A}(\mathbf{b}, \mathbf{e})$ and $90 \mathrm{~A}(\mathbf{c}, \mathbf{f})$ currents.

Figure 11 illustrates the evolutions of the maximum temperature of the cells during their discharges with $18 \mathrm{~A}, 54 \mathrm{~A}$ and $90 \mathrm{~A}$. At low current rates, the evolutions of the maximum temperature of the cells are limited, which reflects the small increases in the surface and the internal temperatures observed for the cells. This can be explained by the fast equilibrium reached at low current rates between the heat generated inside the cells and the heat removed out of the cells. With the increase in the current rate, the curves show steeper slopes, which indicates that faster temperature rises occur during the discharge of the cells. This is due to the larger amount of heat generated inside the cells at high current rates, which prevents the cells from achieving, in a shorter time, a proper dissipation of the heat towards the air in the module.

Compared to the other cells in the module, the maximum temperature of Cell 4 with $20 \%$ initial DoD shows a more pronounced increase in the second half of the discharges. When the cells are discharged with higher current rates $\left(3 I_{t}\right.$ and $\left.5 I_{t}\right)$, the temperature rise for Cell 4 is less than 1.5 times the one observed for the reference cells. At the end of the discharge of the cells with a low current rate $\left(1 I_{t}\right)$, 
the increase in the temperature of Cell 4 is four-times greater compared to that of the reference cells. Figure 11 also demonstrates therefore the increase in the maximum temperature of the cells with their initial DoD.

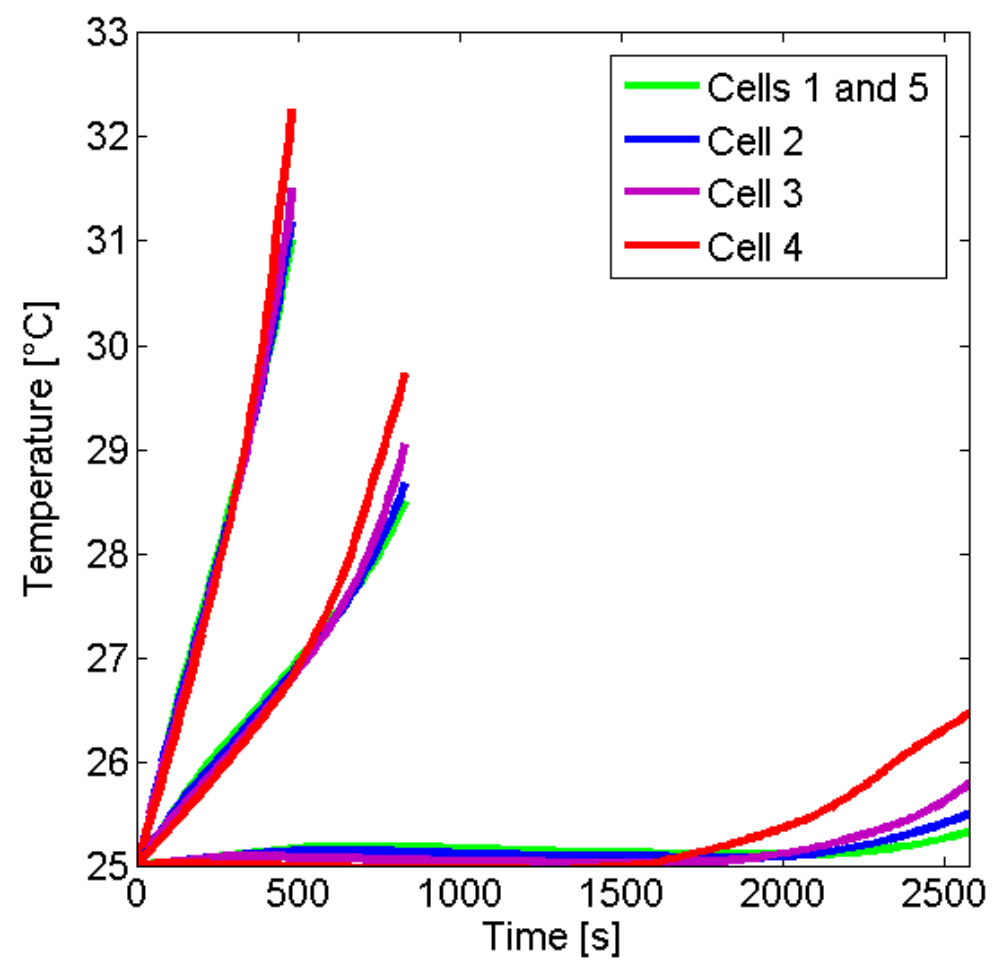

Figure 11. Evolution of the maximum temperature of the cells during (a) $18 \mathrm{~A}$ (b) $54 \mathrm{~A}$ and (c) 90 A discharges.

\subsubsection{Heat Generation}

Figure 12 illustrates the evolution of the heat generation inside the cells during several discharge rates. In reference to Equation (6), the total heat generation results from the sum of the reactive (or reversible) heat and the active and ohmic (or irreversible) heats. In Figure 12a-c, the total heat becomes larger with the current rate, because of the increase in the current flowing through the cells. In the beginning of the discharges, the cells with $20 \%$ initial DoD show a lower total heat compared to the reference cells due to a lower reactive heat. In the middle of the discharges, the total heat generated in the cells is similar. At the end of the discharges, an increase in the total heat is observed with the initial DoD of cells. In Figure 12, a peak coming from the reactive heat is present in the total heat of Cell 4. This peak is followed by an increase at the very end of the discharges due to the active heat. 
(a)

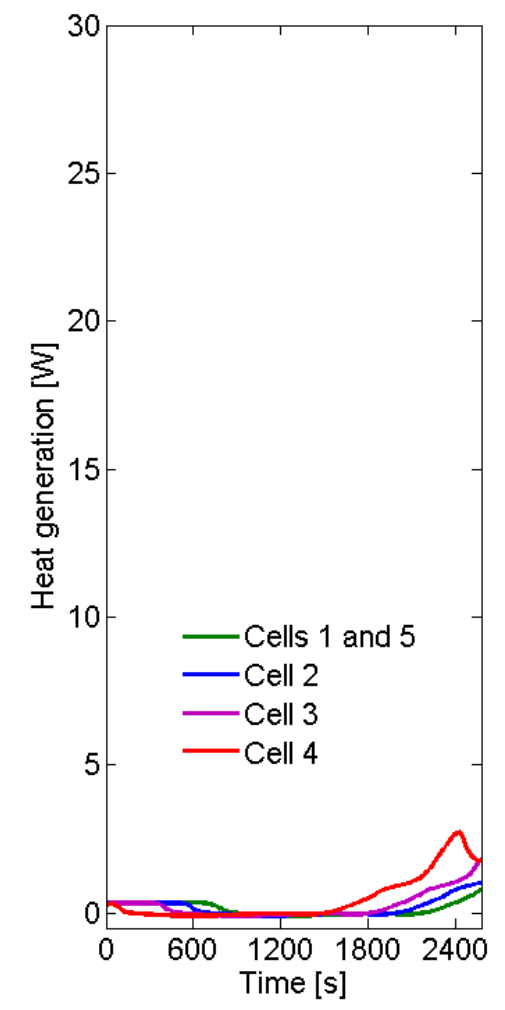

(b)

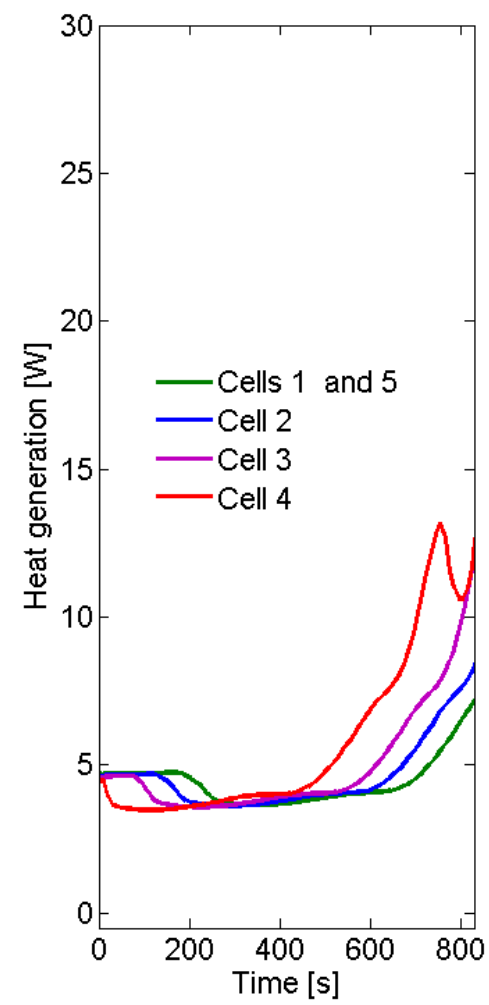

(c)

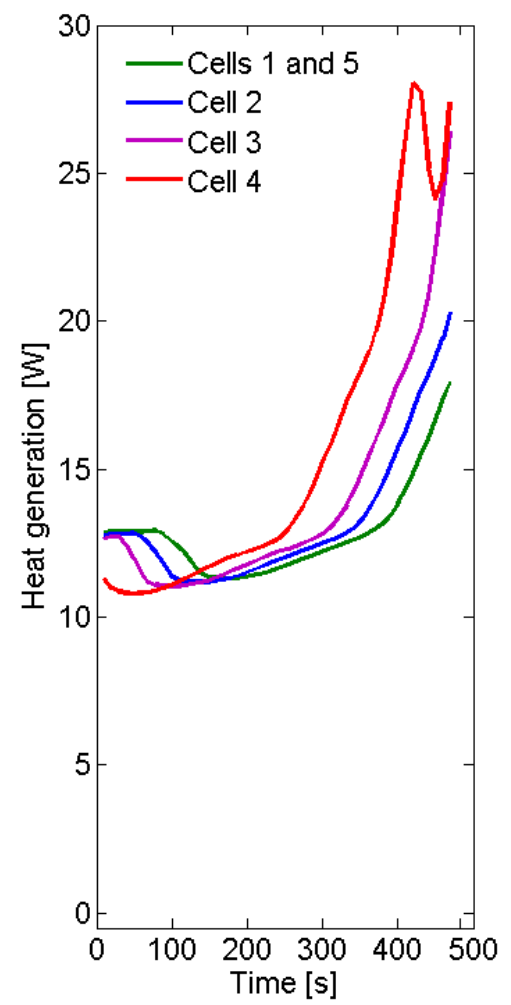

Figure 12. Total heat generation during (a) $1 I_{t}$ (b) $3 I_{t}$ (c) $5 I_{t}$ discharge current rates.

Figure 13 illustrates the difference in the reactive heat of the cells with a non-zero initial DoD and the reference cells during their discharges.

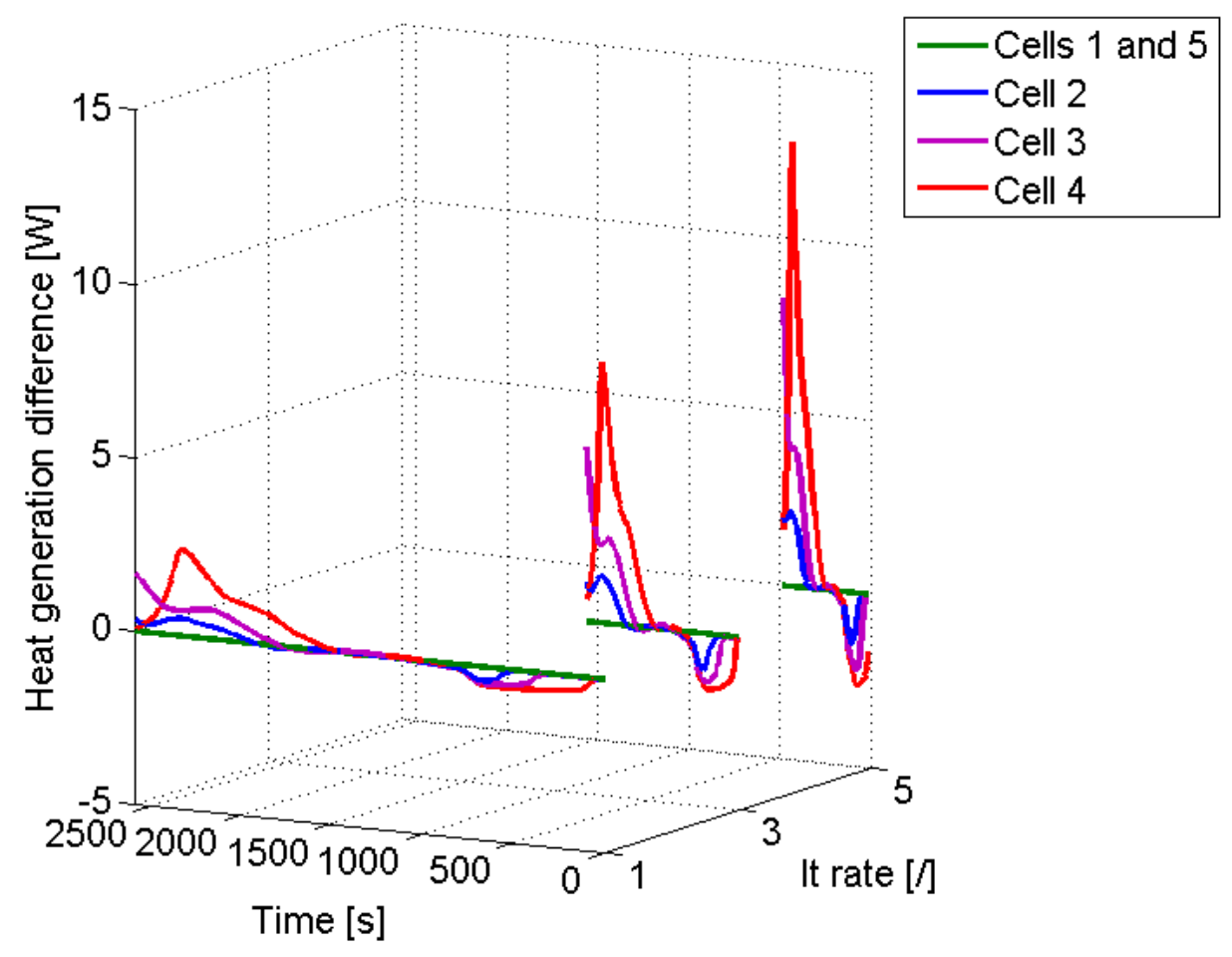

Figure 13. Reactive heat generation differences. 
The reactive heat originates from the heat generation due to the charge transfer involved in the electrochemical reactions at the electrode-electrolyte interfaces. This reactive heat is reversible and is proportional to the changes in the entropy coefficients of the electrodes occurring during the discharge of the cells. If positive, because of the exothermic character of the electrochemical reactions, the reactive heat behaves as a heat source. Similarly, when negative because of the endothermic character of the electrochemical reactions, the reactive heat behaves as a heat sink. In Figure 13, according to the entropy changes of the electrodes, the reactive heat evolves from the heat sink at the beginning to the heat source at the end of the discharges.

At the beginning of the discharges, negative differences are observed for the reactive heat of the cells with a non-zero initial DoD. These cells present a greater negative reactive heat compared to the reference cells because of the greater entropy coefficient reached for their cathode. In the middle of the discharges, no significant differences are observed, since the cells present the same constant reactive heat because of the almost constant entropy coefficient of the cathode. At the end of the discharges, positive differences are noticed in the reactive heat of the cells with a non-zero initial DoD. These cells show a higher reactive heat because of the higher increase in the entropy coefficients of their anode and their cathode near the end of the discharge. Due to the change in the entropy coefficient of the anode, a peak is observed in the reactive heat of Cell 4 near the end of the discharge. This peak corresponds to the one found in the total heat generation of this cell in Figure 12. In Figure 13, because of the proportionality of the reactive heat to the exchange current density involved in the electrode reactions, the differences observed between the reactive heat of the cells in the module are amplified with the increase in the current rate. In Figure 11, the reasons for the lower increase of the temperature for the non-zero DoD cells at the beginning and the higher increases at the end of the discharges are respectively due to the more negative and the more positive characters of the reactive heat.

The active heat is due to the heat generated by the charge transfer at the electrode-electrolyte interfaces, as for the reactive heat. The active heat is irreversible and is proportional in Equation (6) to the electrodes' surface overpotential $\eta$. During the discharge of the cells, the active heat is always positive and behaves therefore as a heat source. In Figure 14, the difference between the active heat generated by the cells with a non-zero initial DoD and the reference cells is illustrated during their discharges. This difference is observed to be always positive, independent of the discharge current rates. At the end of the discharges, high differences occur for the cells with a non-zero initial DoD due to the sharp increase in the open circuit potential of their anode at the end of the discharge, which leads them to higher overpotential $\eta$ compared to those of the reference cells. Because of the proportionality of the active heat to the exchange current density involved in the electrode reactions, greater differences in the active heat of the cells are noticed near the end of the discharge with the increase in the current rate. In reference to Figure 12, the active heat contributes to the last increase after the peak in the total heat of the cells at the very end of their discharges. 


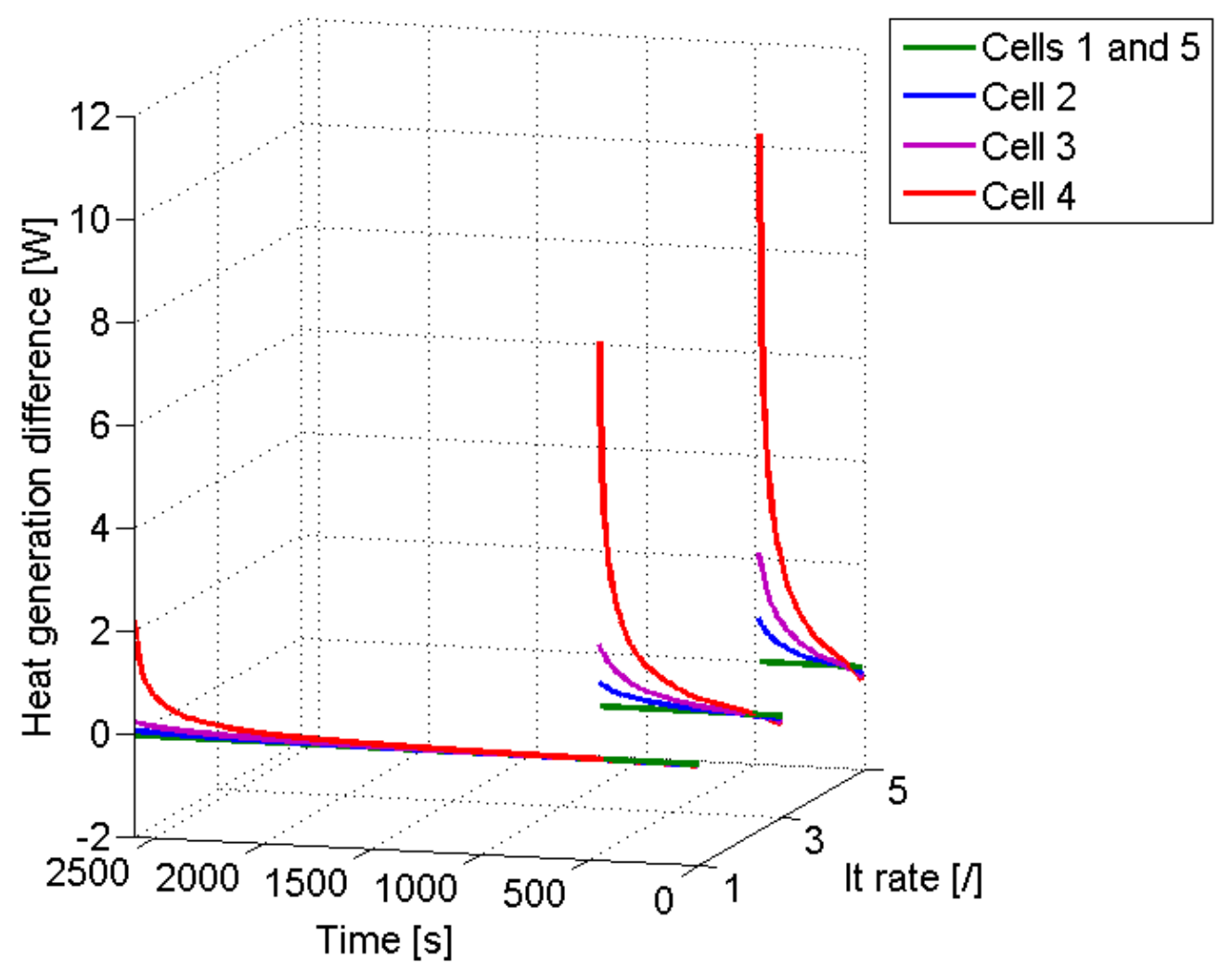

Figure 14. Active heat generation differences.

The ohmic heat is caused by the ohmic heating taking place in both solid and electrolyte phases of the porous electrodes and in the electrolyte. This heat is always positive and, therefore, always behaves as a heat source. The difference between the ohmic heat of the cells with a non-zero initial DoD and the reference cells is illustrated in Figure 15. Because this ohmic heat is linked to the variations in the current and the potential during the electrochemical reactions at the electrodes, the differences are lower in magnitude compared to those observed for the reactive and the active heats. During the discharges with a low current rate, almost no differences are observed between the ohmic heat generated by the cells. For higher current rates, positive and negative differences are clearly identified in the first and second half of the discharges, respectively. This is due to the proportionality of the ohmic heat to the square of the discharge current density involved in the electrochemical reactions. At the early beginning of the discharges, the increase in the difference between the ohmic heats is due to the increase in the voltage loss at the cathode of the cells with a non-zero DoD, as well as to the increase in the concentration of lithium ion in the electrolyte released from the anode towards the cathode. In the second half of the discharge, the decrease in the ohmic heat differences is due to an increased drop in the concentration of lithium ion in the electrolyte reaching the cathode. Compared to the other cells, the decrease in the ohmic heat profile of Cell 4 is more pronounced due to the strong decrease and increase, respectively, in the cathode and in the anode potentials occurring at the end of the complete discharge of the cell. 


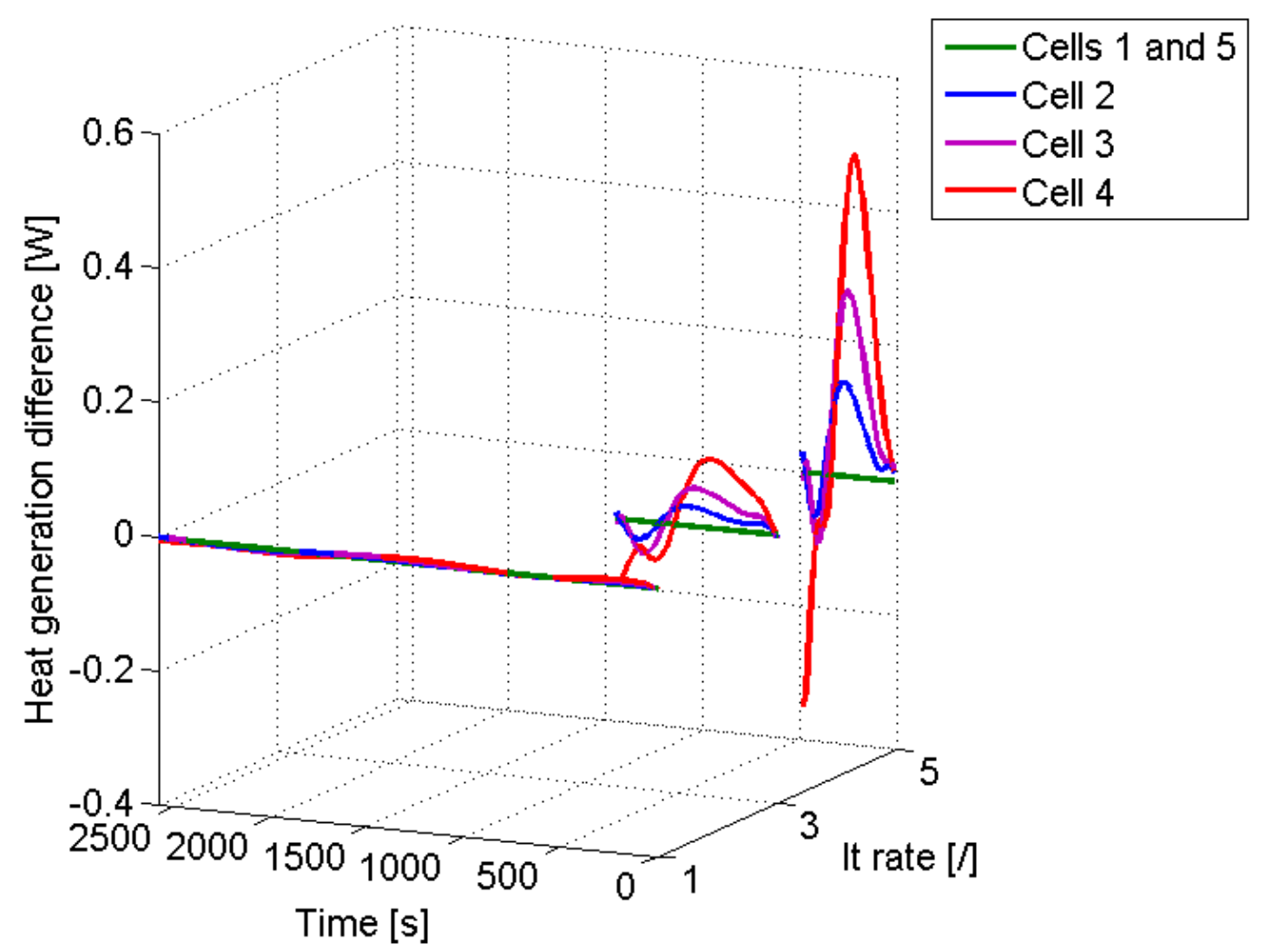

Figure 15. Ohmic heat generation differences.

\section{Conclusions}

In this paper, the thermal behaviour of an unbalanced battery module made of large-size and high-power lithium iron phosphate cylindrical cells is investigated based on its two-dimensional modelling. In the module, several cells are assigned to $5 \%$ up to $20 \%$ initial DoD. Initially, the module is at $25{ }^{\circ} \mathrm{C}$ and is cooled by a $0.059 \mathrm{~kg} / \mathrm{m}^{2} \cdot \mathrm{s}$ air flux. The investigation of the thermal behaviour of the module is achieved during the discharge of the cells with $18 \mathrm{~A}, 54 \mathrm{~A}$ and $90 \mathrm{~A}$ constant currents. From the results, an increase in the internal temperatures of the cells due to the higher total heat generation inside the cells occurs with the increase in the initial DoD and the discharge rate. At the end of the discharges, the highest temperatures are reached for the cells with the highest initial DoD. The major contributors to the total heat inside the cells were found to be the reactive and the active heats. This study demonstrates the effects of the initial DoD of the cells on the temperature distribution, the temperature increase and the heat generation occurring inside an unbalanced battery module made of cylindrical cells.

\section{Acknowledgments}

We acknowledge "Flanders make" for the support to our team.

\section{Author Contributions}

Odile Capron and Ahmadou Samba contributed to the simulations and the writing of this paper. Thierry Coosemans and Peter Van den Bossche made suggestions that contributed to improvements 
in the manuscript. Noshin Omar and Joeri Van Mierlo contributed to the guidance and the supervision of the research. All authors have read and approved the final manuscript.

\section{Conflicts of Interest}

The authors declare no conflict of interest.

\section{List of Symbols (Variables and Parameters)}

\section{Symbols}

\begin{tabular}{|c|c|}
\hline$a_{s}$ & Active surface area $(1 / \mathrm{m})$ \\
\hline $\mathrm{c}$ & lithium ions concentration $\left(\mathrm{mol} / \mathrm{m}^{3}\right)$ \\
\hline$c_{p}$ & Heat capacity $(\mathrm{J} / \mathrm{kg} \cdot \mathrm{K})$ \\
\hline $\mathrm{d}$ & Diameter at the start of the spiral or internal diameter of the cell (m) \\
\hline$D$ & Diffusion coefficient $\left(\mathrm{m}^{2} / \mathrm{s}\right)$ \\
\hline $\mathrm{D}$ & Diameter taken at the end of the spiral or cell diameter $(\mathrm{m})$ \\
\hline$E_{a}$ & Activation energy $(\mathrm{J} / \mathrm{mol})$ \\
\hline $\mathrm{F}$ & Faraday constant, 96,485 C/mol \\
\hline $\mathrm{h}$ & Convection heat transfer coefficient $\mathrm{W} / \mathrm{m}^{2} \cdot \mathrm{K}$ \\
\hline$i_{0}$ & Exchange current density of an electrode reaction $\left(\mathrm{A} / \mathrm{m}^{2}\right)$ \\
\hline$j^{L i}$ & Transfer current due to the intercalation or deintercalation of lithium ions $\left(\mathrm{A} / \mathrm{m}^{3}\right)$ \\
\hline$k$ & Electrochemical reaction rate constant $(\mathrm{m} / \mathrm{s})$ \\
\hline $\mathrm{k}$ & Thermal conductivity $(\mathrm{W} / \mathrm{m} \cdot \mathrm{K})$ \\
\hline $\mathrm{L}$ & Total length of the spiral constituting the internal structure of the cell (m) \\
\hline $\mathrm{L}$ & Length of the cells in the vertical direction (i.e., height) (m) \\
\hline $\mathrm{N}$ & Total number of layers in the jelly roll structure of the cell (/) \\
\hline $\mathrm{N}$ & Total number of cells in the battery module $\left(N_{T} \cdot N_{L}\right)(/)$ \\
\hline$N_{L}$ & Number of cells in the longitudinal direction of the battery module $(/)$ \\
\hline$N_{T}$ & Number of cells in the transverse direction of the battery module $(/)$ \\
\hline Q & Heat generation $\left(\mathrm{W} / \mathrm{m}^{3}\right)$ \\
\hline $\mathrm{r}$ & Radius of the spherical particle (m) \\
\hline $\mathrm{R}$ & Universal gas constant, $8314 \mathrm{~J} / \mathrm{mol} \cdot \mathrm{K}$ \\
\hline$S_{T}$ & Transverse distance between two consecutive cells on the same row (m) \\
\hline $\mathrm{t}$ & Time $(s)$ \\
\hline$t^{+}$ & Transference number of lithium ions (/) \\
\hline $\mathrm{T}$ & Temperature $\left({ }^{\circ} \mathrm{C}\right)$ \\
\hline $\mathrm{U}$ & Open circuit voltage $(\mathrm{V})$ \\
\hline $\mathrm{V}$ & Fluid velocity at the entrance of the module $(\mathrm{m} / \mathrm{s})$ \\
\hline $\mathrm{V}$ & Volume of layer $\left(\mathrm{m}^{3}\right)$ \\
\hline $\mathrm{W}$ & Width of the different layers constituting the jelly roll (m) \\
\hline
\end{tabular}




\section{Greek letters}

$\begin{array}{ll}\alpha & \text { Charge transfer coefficient (/) } \\ \epsilon & \text { Volume fraction }(/) \\ \eta & \text { Overpotential }(\mathrm{V}) \\ \kappa & \text { Ionic conductivity }(\mathrm{S} / \mathrm{m}) \\ \phi & \text { Potential }(\mathrm{V}) \\ \rho & \text { Density }\left(\mathrm{kg} / \mathrm{m}^{3}\right) \\ \sigma & \text { Electrical conductivity }(\mathrm{S} / \mathrm{m})\end{array}$

\section{Subscripts}

$\begin{array}{ll}\text { a } & \text { Anode } \\ \mathrm{c} & \text { Cathode } \\ \mathrm{e} \text { or } 1 & \text { Electrolyte phase } \\ \text { eff } & \text { Effective } \\ \mathrm{f} & \text { Fluid } \\ \mathrm{i} & \text { Inlet } \\ \text { max } & \text { Maximum } \\ \text { measured } & \text { Measured by experiment } \\ \text { model } & \text { Modeled by simulation } \\ \text { o } & \text { Outlet } \\ \mathrm{s} & \text { Solid phase } \\ \mathrm{w} & \text { Wall }\end{array}$

$\begin{array}{ll}\text { Abbreviations } & \\ \text { DoD } & \text { Depth of discharge } \\ \text { EV } & \text { Electric vehicle } \\ \text { HEV } & \text { Hybrid electric vehicle } \\ \text { LFP } & \text { Lithium iron phosphate } \\ \text { MUMPS } & \text { Multifrontal Massively Parallel Solver } \\ \text { SoC } & \text { State of charge }\end{array}$

\section{References}

1. Van den Bossche, P.; Omar, N.; Al Sakka, M.; Samba, A.; Gualous, H.; van Mierlo, J. The Challenge of PHEV Battery Design and the Opportunities of Electrothermal Modeling. In Lithium-Ion Batteries: Advances and Applications; Elsevier: Amsterdam, The Netherlands, 2014; Chapter 11.

2. Van den Bossche, P.; Vergels, F.; van Mierlo, J.; Matheys, J.; van Autenboer, W. SUBAT: An assessment of sustainable battery technology. J. Power Sources 2006, 162, 913-919. 
3. Omar, N.; Daowd, M.; van den Bossche, P.; Hegazy, O.; Smekens, J.; Coosemans, T.; van Mierlo, J. Rechargeable Energy Storage Systems for Plug-in Hybrid Electric Vehicles-Assessment of Electrical Characteristics. Energies 2012, 5, 2952-2988.

4. Mulder, G.; Omar, N.; Pauwels, S.; Meeus, M.; Leemans, F.; Verbrugge, B.; de Nijs, W.; van den Bossche, P.; Six, D.; van Mierlo, J. Comparison of commercial battery cells in relation to material properties. Electrochim. Acta 2013, 87, 473-488.

5. Van Mierlo, J.; van den Bossche, P.; Maggetto, G. Models of energy sources for EV and HEV: Fuel cells, batteries, ultracapacitors, flywheels and engine-generators. J. Power Sources 2004, 128, 76-89.

6. Lu, L.; Han, X.; Li, J.; Hua, J.; Ouyang, M. A review on the key issues for lithium-ion battery management in electric vehicles. J. Power Sources 2013, 226, 272-288.

7. Pesaran, A.A. Battery thermal models for hybrid vehicle simulations. J. Power Sources 2002, 110, 377-382.

8. Sabbah, R.; Kizilel, R.; Selman, J.R. Active (air-cooled) vs. passive (phase change material) thermal management of high power lithium-ion packs: Limitation of temperature rise and uniformity of temperature distribution. J. Power Sources 2008, 182, 630-638.

9. Fathabadi, H. High thermal performance lithium-ion battery module including hybrid active-passive thermal management system for using in hybrid/electric vehicles. Energy 2014, $70,529-538$.

10. Warner, J. Lithium-Ion Battery Packs for EVs. In Lithium-Ion Batteries: Advances and Applications; Elsevier: Amsterdam, The Netherlands, 2014; Chapter 7.

11. Goli, P.; Legedza, S.; Dhar, A.; Salgado, R.; Renteria, J.; Balandin, A. Graphene-enhanced hybrid phase change materials for thermal management of Li-ion batteries. J. Power Sources 2014, 248, 37-43.

12. Renteria, J.; Nika, D.; Balandin, A. Graphene Thermal Properties: Applications in Thermal Management and Energy Storage . J. Appl. Sci. 2014, 4, 525-547.

13. Koo, B.; Goli, P.; Sumant, A.; dos Santos Claro, P.; Rajh, T.; Johnson, C.; Balandin, A.; Shevchenko, E. Toward Lithium Ion Batteries with Enhanced Thermal Conductivity. ACS Nano 2014, 8, 7202-7207.

14. Evanoff, K.; Khan, J.; Balandin, A.; Magasinski, A.; Ready, W.; Fuller, T.; Yushin, G. Towards Ultrathick Battery Electrodes: Aligned Carbon Nanotube-Enabled Architecture. Adv. Mater. 2012, $24,533-537$.

15. Ma, Y.; Teng, H.; Thelliez, M. Electro-Thermal Modeling of a Lithium-ion Battery System. SAE Int. J. Engines 2010, 3, 306-317.

16. Wang, T.; Tseng, K.; Zhao, J.; Wei, Z. Thermal investigation of lithium-ion battery module with different cell arrangement structures and forced air-cooling strategies. Appl. Energy 2014, 134, 229-238.

17. He, F.; Li, X.; Ma, L. Combined experimental and numerical study of thermal management of battery module consisting of multiple Li-ion cells. Int. J. Heat Mass Transf. 2014, 72, 622-629.

18. Li, X.; He, F.; Ma, L. Thermal Management of cylindrical batteries investigated using wind tunnel testing and computational fluid dynamics simulation. J. Power Sources 2013, 238, 395-402. 
19. Xing, Y.; Ma, E.; Tsui, K.; Pecht, M. Battery Management Systems in Electric and Hybrid Vehicles. Energies 2011, 4, 1840-1857.

20. Capron, O.; Samba, A.; Omar, N.; Gualous, H.; van den Bossche, P.; van Mierlo, J. Battery Thermal Modelling-Assessment of heat distribution and optimization of battery design concept. In Proceedings of the 2013 International Conference on Renewable Energy Research and Applications (ICRERA), Madrid, Spain, 20-23 October 2013; pp. 304-309.

21. Doyle, M.; Fuller, T.; Newman, J. Modeling of Galvanostatic Charge and Discharge of the Lithium/Polymer/Insertion Cell. J. Electrochem. Soc. 1993, 140, 1526-1533.

22. Fuller, T.; Doyle, M.; Newman, J. Simulation and Optimization of the Dual Lithium Ion Insertion Cell. J. Electrochem. Soc. 1994, 141, 1-10.

23. Saw, L.; Ye, Y.; Tay, A.A.O. Electrochemical-thermal analysis of 18650 Lithium Iron Phosphate cell. Energy Convers. Manag. 2013, 75, 162-174.

24. Prada, E.; Di Domenico, D.; Creff, Y.; Bernard, J.; Sauvant-Moynot, V.; Huet, F. Simplified Electrochemical and Thermal model of LiFePO4, Graphite Li-Ion Batteries for fast charge applications. J. Electrochem. Soc. 2012, 159, A1508-A1519.

25. Jiang, F.; Peng, P.; Sun, Y. Thermal analyses of LiFePO4/graphite battery discharge processes. J. Power Sources 2013, 243, 181-194.

26. Inui, Y.; Kobayashi, Y.; Watanabe, Y.; Watase, Y.; Kitamura, Y. Simulation of temperature distribution in cylindrical and prismatic lithium ion secondary batteries. Energy Convers. Manag. 2007. 48, 2103-2109.

27. Somasundaram, K.; Birgersson, E.; Mujumdar, A. Thermal-electrochemical model for passive thermal management of a spiral-wound lithium-ion battery. Power Sources 2012, 203, 84-96.

28. Ye, Y.; Shi, Y.; Tay, A.A.O. Electro-thermal cycle life model for lithium iron phosphate battery. J. Power Sources 2012, 217, 509-518.

29. Somasundaram, K. Mathematical Modeling of Transport Phenomena in Electrochemical Energy Storage Systems. Ph.D. Thesis, Department of Mechanical Engineering, National University of Singapore, Singapore, 2012.

30. PEC. Available online: http://www.peccorp.com/SBT0550-tabs-glance.html (accessed on 2 February 2015).

31. Samba, A.; Louahlia-Gualous, H.; le Masson, S.; Nörterhäuser, D. Two-phase thermosyphon loop for cooling outdoor telecommunication equipments. Appl. Therm. Eng. 2013, 50, 1351-1360.

32. Zukauskas, A. Heat transfer from tubes in crossflow. Adv. Heat Transf. 1972, 8, 93-160.

33. Martinez, C.; Sorlien, D.; Goodrich, R.; Chandler, L.; Magnuson, D. Using Cell Balancing to Maximize the Capacity of Multi-cell Li-Ion Battery Modules. Available online: http://www.intersil.com/content/dam/Intersil/documents/an16/an167.pdf (accessed on 25 June 2015).

(c) 2015 by the authors; licensee MDPI, Basel, Switzerland. This article is an open access article distributed under the terms and conditions of the Creative Commons Attribution license (http://creativecommons.org/licenses/by/4.0/). 